\title{
Mechanical fracture and microstructural parameters of alkali-activated materials with a ceramic precursor
}

\author{
Martin Lipowczan ${ }^{1}$, Iva Rozsypalová2, Patrik Bayer ${ }^{3}$, Petr Daněk ${ }^{4}$ \\ David Lehký5, Pavla Rovnaníková6, Zbyněk Keršner ${ }^{7}$
}

\begin{abstract}
:
Four sets of alkali-activated aluminosilicate composites based on ceramic precursors were studied in terms of their characterization by mechanical fracture and microstructural parameters. Composites made with brick dust as a precursor and with alkaline activator variants of differing silicate modulus (Ms $=0.8,1.0,1.2$, 1.4 and 1.6) were investigated. The filler used with first two sets of composites was quartz sand, while in the case of the other two sets it was brick rubble; precursor particle size range variants: $0 \div 1 \mathrm{~mm}$ and $0 \div 0.3 \mathrm{~mm}$. The test specimens had nominal dimensions of $40 \times 40 \times 160 \mathrm{~mm}$ and were provided with notches at midspan after 28 days of hardening. The notches extended up to $1 / 3$ of the height of the specimens, which were subjected to three-point bending tests in which force vs. displacement diagrams were recorded. Values were determined for the static modulus of elasticity, effective fracture toughness, effective toughness and specific fracture energy using the Effective Crack Model and the Work-of-Fracture method. At the same time, values were identified for the static modulus of elasticity, tensile strength and specific fracture energy using the inverse method based on a neural network ensemble. The measured and identified parameters are in very good agreement. The silicate modulus, type of filler and refinement of the precursor significantly influenced the mechanical fracture parameters of the composites. The microstructure of composites with a coarser precursor was also described.
\end{abstract}

\section{KEYWORDS:}

alkali-activated aluminosilicate; artificial neural network; fracture test; load-displacement diagram; mechanical fracture parameters

\section{Introduction}

With respect to the drive to reduce the environmental impact of $\mathrm{CO}_{2}$ production, low-carbon materials are being sought. Particular attention is being paid to materials that are formed as waste during the course of other technical processes. Use is made of ashes from coal combustion in power plants as well as slags from the metallurgical industry; other industrial wastes that exhibit a silicate character and a certain degree of pozzolanic activity are also being tested.

${ }^{1}$ Brno University of Technology, Faculty of Civil Engineering, Brno, Czech Republic, e-mail: Martin.Lipowczan@vutbr.cz, orcid id: 0000-0003-1541-687X

2 Brno University of Technology, Faculty of Civil Engineering, Brno, Czech Republic, e-mail: iva.rozsypalova@vutbr.cz, orcid id: 0000-0003-3109-3820

3 Brno University of Technology, Faculty of Civil Engineering, Brno, Czech Republic, e-mail: bayer.p@fce.vutbr.cz, orcid id: 0000-0001-7866-1085

4 Brno University of Technology, Faculty of Civil Engineering, Brno, Czech Republic, e-mail: petr.danek@vutbr.cz, orcid id: 0000-0001-8489-9452

5 Brno University of Technology, Faculty of Civil Engineering, Brno, Czech Republic, e-mail: lehky.d@fce.vutbr.cz, orcid id: 0000-0001-8176-4114

${ }^{6}$ Brno University of Technology, Faculty of Civil Engineering, Brno, Czech Republic, e-mail: rovnanikova.p@fce.vutbr.cz, orcid id: 0000-0002-6732-788X

7 Brno University of Technology, Faculty of Civil Engineering, Brno, Czech Republic, e-mail: kersner.z@fce.vutbr.cz, orcid id: 0000-0003-4724-6166 
Brick rubble is a material which was used in the past as an admixture in mortars for masonry and plastering. Sources of brick waste include material remaining after the demolition of brick buildings and, more recently, the production of calibrated thermal insulating brick blocks. The waste brick powder is generated during the spot-facing of the blocks.

These waste materials can be used in mixtures with Portland cement in concrete as supplementary cementitious materials, or they can be used directly for the production of blended cements. Due to the high level of $\mathrm{CO}_{2}$ released during cement production, attention is now being paid to the alkaline activation of these materials. The alkaline activation of blast furnace slag was first described by [1], while later Glukhovsky addressed this topic, introducing the term "alkaline cements" [2]. In the 1970s, Davidovits[3] developed and patented binders that make use of the alkaline activation of heat-treated kaolin (metakaolin), the resulting products being named "geopolymers".

These materials are formed through the reaction of aluminosilicates as a precursor and sodium or potassium hydroxide or silicate as an alkaline activator. For the purpose of the experiments, waste brick powder was selected as the precursor for the preparation of alkali-activated materials.

This chapter is focused on the advanced investigation of mechanical fracture properties and partial evaluation of the microstructure of alkali-activated materials prepared via the alkaline activation of waste brick powder using a potassium activator with different silicate moduli [4-6].

\section{Theoretical background}

When describing the nature of alkali-activated materials, two types are basically distinguished. The first type of products are made using aluminosilicates (e.g. metakaolin, metashale, metamontmorillonite, etc.) in which heat treatment leads to the loss of bound water and collapse of the crystal lattice. This process makes them reactive in an alkaline environment. The resulting products are called "geopolymers".

The manufacture of the second type of products involves the alkaline activation of raw materials that contain other elements (e.g. calcium) as a component together with silicon and aluminium. This group of materials includes fly ashes, metallurgical slags, brick dust and others. Since these raw materials contain calcium compounds and aluminosilicates, various products are formed according to their composition. These materials are called Alkali-Activated Alumino Silicates (AAAS).

As the main components of alkali-activated materials (precursors) are characterized by an appropriate chemical and mineralogical composition. Amorphous phases are preferable for the alkaline activation process. Mixtures of alkali silicates and alkali hydroxides are frequently used as the alkaline component in AAAS composites.

The reaction mechanism and resulting reaction products have been described by many investigators [7-9] gives two models of reaction mechanisms of alkaline activation. The first model concerns the activation of materials containing silicium and calcium, such as blast furnace slags: the main reaction products are calcium-silicate-hydrate ( $\mathrm{CSH})$ gels. The second involves the alkaline activation of aluminosilicates (silicium and aluminium) such as metakaolin, with geopolymers as the reaction products. The same results were found by Yip et al. [10]. Puertas et al. [11] activated blast furnace slag with sodium hydroxide; hydrotalcite $\left(\mathrm{Mg}_{6} \mathrm{Al}_{2} \mathrm{CO}_{3}(\mathrm{OH})_{16} \cdot 4 \mathrm{H}_{2} \mathrm{O}\right)$, calcite $\left(\mathrm{CaCO}_{3}\right)$ and $\mathrm{CSH}$ were found in the reaction products. Other authors [12] investigated reaction products from the alkaline activation of fly ashes. They found zeolitic phases such as sodalite $\left(\mathrm{Na}_{4} \mathrm{Al}_{3} \mathrm{Si}_{3} \mathrm{O}_{12} \mathrm{OH}\right)$ and herschelite $\left(\mathrm{NaAlSi}_{2} \mathrm{O}_{6} \cdot 3 \mathrm{H}_{2} \mathrm{O}\right)$ using X-ray diffraction analysis.

The products of the alkaline activation of aluminosilicate materials depend on the chemical and mineralogical composition, and on the amorphous phase content of the precursor, the type of alkaline activator used, and the ratio of the components ( $\mathrm{Si}, \mathrm{Al}, \mathrm{Na}$, and $\mathrm{K}$ ).

The alkali-activation of brick rubble has been a topic of investigation for many years. Most of the currently existing publications are focused on the alkaline activation of aluminosilicate materials using sodium compounds [13-20]; only some research is focused on alkaline activation using potassium compounds [14-26]. 
Waste brick powder ranks among those materials which are typically used for alkaline activation. Brick body contains mainly $\mathrm{SiO}_{2}, \mathrm{Al}_{2} \mathrm{O}_{3}$ and $\mathrm{Fe}_{2} \mathrm{O}_{3}$, as well as small amounts of $\mathrm{CaO}, \mathrm{MgO}$, $\mathrm{Na}_{2} \mathrm{O}$ and $\mathrm{K}_{2} \mathrm{O}$. The components present in brick body are crystalline and also amorphous.

The mechanical properties of AAAS composites depend on several factors:

- the ratio of the components $\mathrm{SiO}_{2} / \mathrm{Al}_{2} \mathrm{O}_{3} ; \mathrm{Na}_{2} \mathrm{O}, \mathrm{K}_{2} \mathrm{O} / \mathrm{Al}_{2} \mathrm{O}_{3} ; \mathrm{SiO}_{2} / \mathrm{Na}_{2} \mathrm{O}, \mathrm{K}_{2} \mathrm{O}$ is an important factor $[27,28]$;

- the silicate moduli of the alkaline activator [29];

- the ratio of the precursor mass and amount of alkaline activator;

- the ratio of binder to aggregate, and the type and size of aggregate particles is important in AAAS composites with aggregate.

\section{Materials and methods}

\subsection{Alkali-activated materials with a ceramic precursor}

Waste brick powder from the grinding process was used as aluminosilicate material for the preparation of AAAS composites. The waste material is produced by a brick-kiln located in the Czech Republic (HELUZ cihlářskýprůmyslv.o.s., Libochovice). Its chemical composition is shown in Table 1 (LOI stands for loss on ignition in this table), while its mineralogical composition is depicted in Table 2.

\section{Table 1}

Chemical composition of brick powder

\begin{tabular}{|l|l|l|l|}
\hline Component & Content (\%) & Component & Content (\%) \\
\hline $\mathrm{SiO}_{2}$ & 51.0 & $\mathrm{Al}_{2} \mathrm{O}_{3}$ & 15.6 \\
\hline $\mathrm{CaO}$ & 16.7 & $\mathrm{Fe}_{2} \mathrm{O}_{3}$ & 5.09 \\
\hline $\mathrm{Na}_{2} \mathrm{O}$ & 0.415 & $\mathrm{TiO}_{2}$ & 0.818 \\
\hline $\mathrm{K} 2 \mathrm{O}$ & 2.71 & $\mathrm{SO}_{3}$ & 1.30 \\
\hline $\mathrm{MgO}$ & 2.29 & $\mathrm{LOI}$ & 2.85 \\
\hline
\end{tabular}

Table 2

Mineralogical composition of brick powder

\begin{tabular}{|l|l|l|l|}
\hline Component & Content (\%) & Component & Content (\%) \\
\hline Anorthite & 13.4 & Quartz & 29.4 \\
\hline Gehlenite & 2.6 & Illite & 19.8 \\
\hline Hematite & 2.8 & Calcite & 1.5 \\
\hline Orthoclase & 8.9 & Amorphousphase & 21.8 \\
\hline
\end{tabular}

The waste brick material was dried at a temperature of $105^{\circ} \mathrm{C}$ to a constant weight, and then sieved using a $4 \mathrm{~mm}$ sieve. Subsequently, the powder was passed through a sieve with a mesh size of $1 \mathrm{~mm}$; two fractions were obtained: $0 \div 1 \mathrm{~mm}$ and $1 \div 4 \mathrm{~mm}$. The first fraction (brick powder) was used as a precursor; the second fraction (brick rubble) was used as aggregate. Another part of dried waste brick material was ground to the grain size below $0.3 \mathrm{~mm}$ that was used as precursor. The particle size Dpercentile of the $0 \div 0.3 \mathrm{~mm}$ fraction is for D10 $=0.885 \mu \mathrm{m}$, D50 $=9.600 \mu \mathrm{m}$, and D90 $=155.416 \mu \mathrm{m}$, and the particle size Dpercentile of the fraction $0 \div 1 \mathrm{~mm}$ is D10 $=2.489 \mu \mathrm{m}, \mathrm{D} 50=31.091 \mu \mathrm{m}$ and D90 $=226.211 \mu \mathrm{m}$.

Potassium water glass (produced by Vodnísklo, a. s., Czech Republic) contains $26.23 \% \mathrm{SiO}_{2}$ and $12.06 \% \mathrm{~K}_{2} \mathrm{O}$. Five AAAS composite variantswere devised. Waste brick powder with a particle size of $0 \div 1 \mathrm{~mm}$ was mixed with modified solutions of potassium water glass with silicate moduli $\left(\mathrm{SiO}_{2} / \mathrm{K}_{2} \mathrm{O}\right)$ of $\mathrm{Ms}=0.8 ; 1.0 ; 1.2 ; 1.4$ and 1.6. The potassium alkaline activator was selected due to the resultant lower tendency of the hardened composite to form efflorescence.

Two sorts of aggregate were added to the mixtures. Quartz sand composed of three fractions in the ratio 1:1:1 was used as the aggregate in the first set of AAAS composites (PG1 
$0.063 \div 1.00 \mathrm{~mm}$, PG2 $0.25 \div 4.00 \mathrm{~mm}$ and PG3 $1.00 \div 4.00 \mathrm{~mm}$ ); for the second and third set of composites $1 \div 4 \mathrm{~mm}$ brick rubble was used. For one $1000 \mathrm{~g}$ batch of waste brick powder, $450 \mathrm{~g}$ potassium silicate (potassium water glass) was used along with five differing amounts of potassium hydroxide $(219.5,162.5,125.0,98.0$ and $78.0 \mathrm{~g})$. Water was added in the amounts needed to give the mixtures the same consistency. In these mixtures the S/Al ratio was 4.07. Specimens with dimensions of $40 \times 40 \times 160 \mathrm{~mm}$ were prepared. After hardening, the specimens were removed from their moulds, wrapped in PE foil and stored until testing took place.

An overview of the extensive experimental campaign that was carried out can be found in Table 3.

Table 3

Sets with different precursor particle size ranges, types of aggregate and silicate moduli Ms

\begin{tabular}{|l|l|l|l|l|l|l|}
\hline Precursor & Aggregate & Ms $=0.8$ & Ms $=1.0$ & Ms $=1.2$ & Ms $=1.4$ & Ms $=1.6$ \\
\hline $0 \div 1 \mathrm{~mm}$ & quartz sand & 37_DVS & 38_DVS & 39_DVS & 40_DVS & 41_DVS \\
\hline $0 \div 1 \mathrm{~mm}$ & brick rubble & 42_DVS & 43_DVS & 44_DVS & 45_DVS & 46_DVS \\
\hline $0 \div 0.3 \mathrm{~mm}$ & brick rubble & 47_DVS & 48_DVS & 49_DVS & 50_DVS & 51_DVS \\
\hline $0 \div 0.3 \mathrm{~mm}$ & quartz sand & 52_DVS & 53_DVS & 54_DVS & 55_DVS & 56_DVS \\
\hline
\end{tabular}

\subsection{Fracture test}

Test specimens with nominal dimensions of $40 \times 40 \times 160 \mathrm{~mm}$ were producedfrom the three types of AAAS composite defined above as subset 37_DVS to 51_DVS. After 28 days of hardening, the beams were provided with notches cut to $1 / 3$ of the beam depth at midspan. Five or six specimens from each composite were tested. The beams were subjected to threepoint bending tests; the span of the supports was $140 \mathrm{~mm}$. Force vs. midspan deflection diagrams (F-d diagrams) were recorded. After these diagrams had been corrected, values were obtained for the static modulus of elasticity, effective fracture toughness, effective toughness and specific fracture energy using the Effective Crack Model (ECM) [4] and the Work-ofFracture (WoF) method according to RILEM TC-50 FMC [30]. After the fracture experiments had been conducted, the informative compressive strength was determined on one of the fractured parts of each specimen. The F-d diagrams obtained from the experiments are depicted in Figure 1.

Accompanying specimens were also prepared and tested in order to obtain their compressive and flexural strengths after 7, 28 and 90 days. The strengths were determined in a hydraulic testing machine.

\subsection{Porosimetry and thermal gravimetric analyses}

At 90 days of hardening, the microstructures of the resulting AAAS products were characterized. The pore size distribution in the hardened material was determined using a PoreSizer 9310 porosimeter (Micromeritics, USA). Thermogravimetric analysis was performed by a Netsch STA 2500 instrument. The microstructure was monitored by a MIRA3 XMU scanning electron microscope. The samples were pre-gilded before scanning. The microstructures are shown at magnifications of $1000 \times$ and $5000 \times$ in the micrographs (Figs. 9 and 10).

\subsection{Numerical simulation and inverse analysis}

Along with the classical evaluation of mechanical fracture parameters from fracture tests, identification of parameters was carried out using the inverse method based on a neural network ensemble (NNE). Values were identified for static modulus of elasticity, tensile strength and specific fracture energy; the characteristic length was calculated. The inverse procedure developed by Novák and Lehký [31] transforms fracture test response data into the desired mechanical fracture parameters. This approach is based on matching laboratory measurements with the results gained by reproducing the same test numerically [32]. 

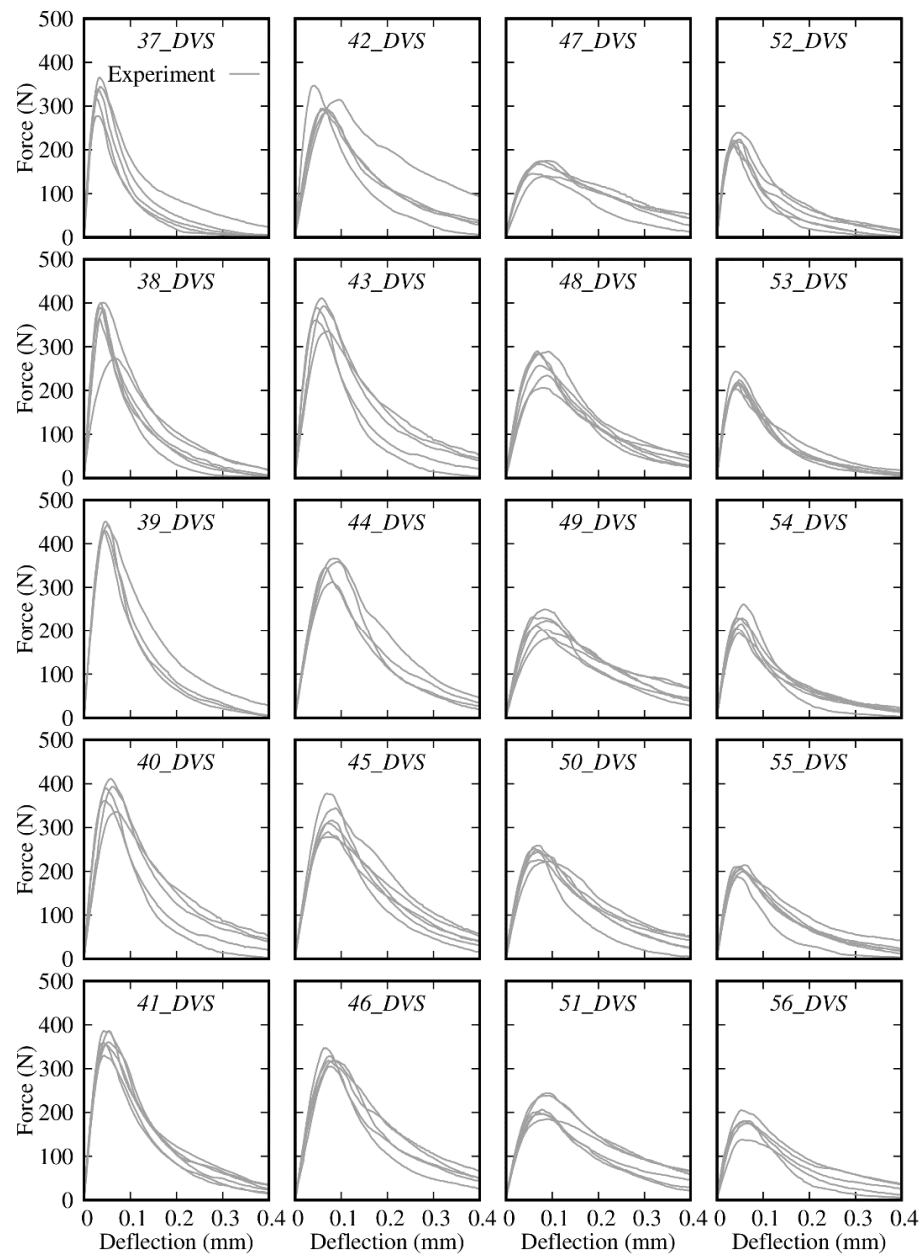

Fig. 1. Force vs. midspan deflection diagrams obtained from experiments

The ATENA FEM program [33] was employed for the numerical simulation of the fracture test. The 3D NonLinear Cementitious 2 material model was selected to govern the gradual evolution of localized damage. The computational model of the test specimens is shown in Figure 2 left.
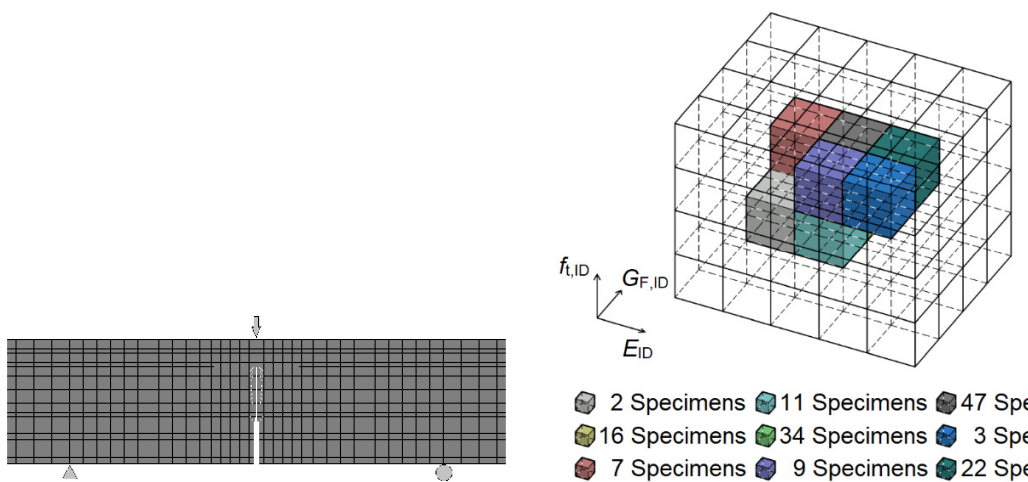

2 Specimens 11 Specimens 47 Specimens 16 Specimens 34 Specimens 3 Specimens 7 Specimens 9 Specimens 22 Specimens

Fig. 2. The computational model (left) and activated subspaces for the studied AAAS composites (right) 
The cornerstone of the inverse method is the artificial neural network (ANN), which is used as a surrogate model of an unknown inverse function between the input mechanical fracture parameters and the corresponding response parameters. A three-dimensional space defined by three mechanical fracture parameters - modulus of elasticity EID, tensile strength $\mathrm{ft}, \mathrm{ID}$, and specific fracture energy GF,ID - is divided into several subspaces (Fig. 2). Every subspace contains a single robust ANN trained for a limited range of parameters. In the inverse procedure, the ANNs are used (activated) separately or in the form of an NNE, depending on the response of the identified sample. The best strategy is automatically selected to achieve the most accurate results for a wide range of different materials while maintaining reasonable computational demands. An example of activated subspaces for the studied AAAS composites is shown in Figure 2 right. The final set of mechanical fracture parameters is then calculated by simulating the ANN with the obtained response parameters. For more detailed description of the NNEbased inverse analysis method see [34].

The classification of specimens into corresponding parameter subspaces is shown in Table 4 .

Table 4

Classification of specimens into corresponding parameter subspaces

\begin{tabular}{|c|c|c|c|}
\hline Subspace & $\begin{array}{l}\text { Ranges: } \\
\text { EID (GPa)|ft,ID (MPa)|GF,ID (J·m-2) }\end{array}$ & $\begin{array}{l}\text { Set } \\
\text { (number of specimens) }\end{array}$ & Sum \\
\hline Light grey & $(1.17 ; 3.63)|(0.54 ; 1.21)|(9 ; 34.79)$ & 47 (1); 56 (1) & 2 \\
\hline Yellow & $(1.17 ; 3.63)|(0.54 ; 1.21)|(28.46 ; 110)$ & $\begin{array}{l}47 \text { (5); } 48 \text { (1); } 49 \text { (4); } 50(1) ; \\
51 \text { (4); } 56(1)\end{array}$ & 16 \\
\hline Red & $(1.17 ; 3.63)|(0.99 ; 3.41)|(28.46 ; 110)$ & $\begin{array}{l}42(1) ; 46(2) ; 48(1) ; 49(2) ; \\
50(1)\end{array}$ & 7 \\
\hline Light blue & $(2.97 ; 8.03)|(0.54 ; 1.21)|(9 ; 34.79)$ & $\begin{array}{l}47 \text { (1); } 52(3) ; 53(4) ; 54(1) ; \\
55 \text { (1); } 56 \text { (1) }\end{array}$ & 11 \\
\hline Light green & $(2.97 ; 8.03)|(0.54 ; 1.21)|(28.46 ; 110)$ & $\begin{array}{l}45 \text { (1); } 47 \text { (2); } 48 \text { (1); } 49(3) ; \\
50 \text { (3); } 51 \text { (6); } 52(3) ; 53(3) ; \\
54 \text { (4); } 55(5) ; 56(3)\end{array}$ & 34 \\
\hline Violet & $(2.97 ; 8.03)|(0.99 ; 3.41)|(9 ; 34.79)$ & $52(3) ; 53(4) ; 54(2)$ & 9 \\
\hline Dark grey & $(2.97 ; 8.03)|(0.99 ; 3.41)|(28.46 ; 110)$ & $\begin{array}{l}38 \text { (2); } 40 \text { (3); } 41 \text { (3); } 42 \text { (4); } \\
43 \text { (5); } 44 \text { (4); } 45 \text { (6); } 46 \text { (5); } \\
48 \text { (4); } 49 \text { (2); } 50(4) ; 51 \text { (1); } \\
52 \text { (1); } 53(1) ; 54(2)\end{array}$ & 47 \\
\hline Blue & $(6.57 ; 16.83)|(0.99 ; 3.41)|(9 ; 34.79)$ & $37(3)$ & 3 \\
\hline Dark green & $(6.57 ; 16.83)|(0.99 ; 3.41)|(28.46 ; 110)$ & $\begin{array}{l}37(3) ; 38(5) ; 39(4) ; 40(3) ; \\
41(6) ; 42(1)\end{array}$ & 22 \\
\hline
\end{tabular}




\section{Achieved results and discussion}

The AAAS composites with quartz sand and with brick powder $0 \div 1 \mathrm{~mm}$ as the precursor (37_DVS - 41_DVS) increased in strength over time (Fig. 3). The changes in flexural strengths over time were low, while the compressive strengths increased significantly. Compressive strengths after 7 and 28 days did not differ depending on the silicate moduli of the alkaline activator; the strength increased with increases in silicate moduli after 90 days. The alkaline activator contains a sufficient amount of $\mathrm{K}_{2} \mathrm{O}$ even in the case of a high silicate modulus of Ms = 1.6. The composition of the activator is sufficient for it to react with the precursor present in the reaction mixture.

The AAAS composites with quartz sand and with brick powder $0 \div 0.3 \mathrm{~mm}$ as the precursor (52_DVS - 56_DVS) decreased with increasing silicate moduli after 7 days, consequently, the trend is reversed (Fig. 3). The compressive strength decreases over time in dependence on silicate moduli of alkaline solution.

a)
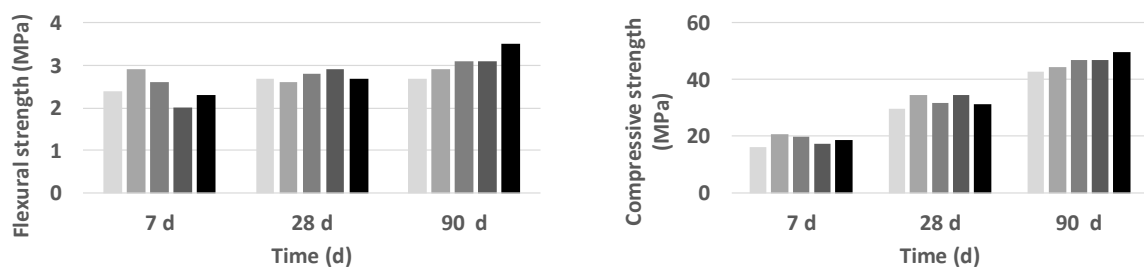

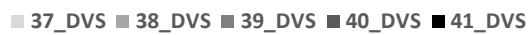

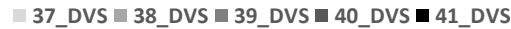

b)
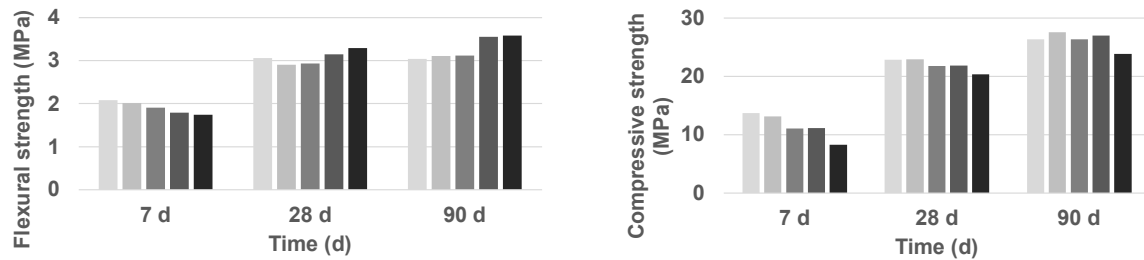

52_DVS $\backsim 53-D V S \backsim 54$ DVS $\backsim 55$ DVS $\backsim 56$ DVS

52_DVS $₫ 53-D V S \backsim 54$ DVS $\because 55$ _DVS $\backsim 56$ _DVS

Fig. 3. Flexural and compressive strengths of composites with quartz sand and brick powder: a) $0 \div 1 \mathrm{~mm}$ as the precursor, b) $0 \div 0.3 \mathrm{~mm}$ as the precursor

a)
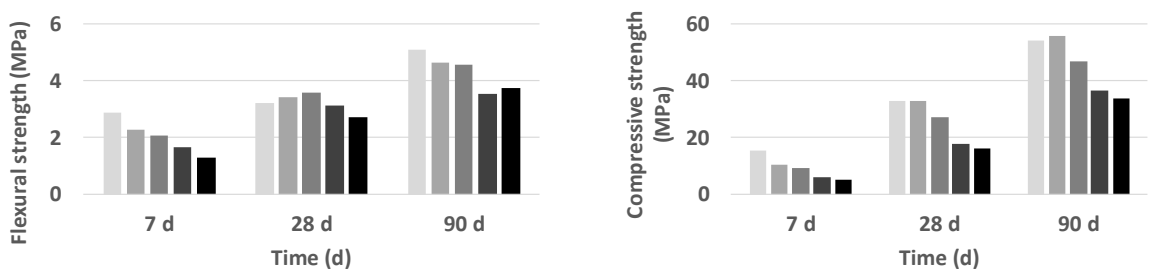

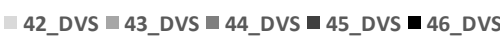

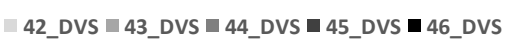

b)
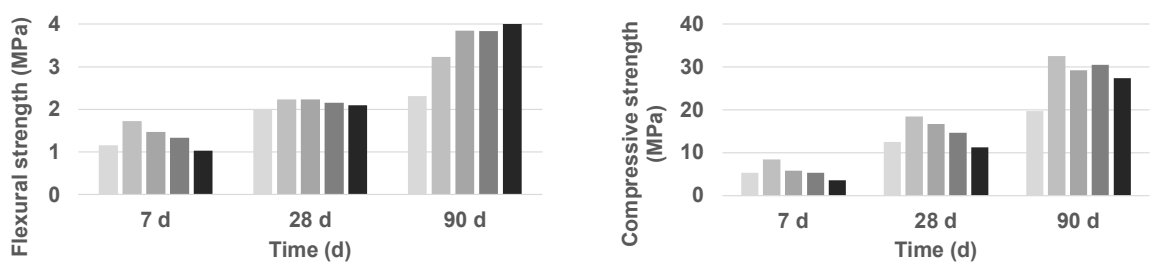

-47_DVS $\because 48$ DVS $\because 49$ DVS $\because 50$ DVS $\because 51$ DVS

$\because 47$ DVS $\backsim 48$ DVS $\backsim 49$ _DVS $=50$ DVS $\because 51$ DVVS

Fig. 4. Flexural and compressive strengths of composites with brick rubble and brick powder: a) $0 \div 1 \mathrm{~mm}$ as the precursor, b) $0 \div 0.3 \mathrm{~mm}$ as the precursor 
The AAAS composites with brick rubble as an aggregate and with brick powder $0 \div 1 \mathrm{~mm}$ as the precursor decreased their strengths over time (42_DVS - 46_DVS) (Fig. 4a). The strengths decrease over time in a manner that is dependent on the silicate moduli of the alkaline activator. The strengths are the highest for the composites with the lowest silicate moduli of alkaline activator because they have the highest $\mathrm{K}_{2} \mathrm{O}$ content. Both brick dust and the surface of brick rubble react with alkaline activator in AAAS composites. The lower amount of $\mathrm{K}_{2} \mathrm{O}$ in the activator with higher silicate moduli leads to a decrease in strength.

The AAAS composites with brick rubble as an aggregate and with brick powder $0 \div 0.3 \mathrm{~mm}$ as the precursor (47_DVS - 51_DVS) (Fig. 4b). The compressive strength decreased over time in dependence on silicate moduli. Sample 47_DVS is different, it always has the lowest strength.

The results of the porosimetric measurements were related to the strengths after 90 days, when the chemical reactions forming the binder phases and the formation of a stable structure are expected to end. The strengths and porosity vary with the grain size of the precursor and the type of aggregate, as well as with the value of the silicate modulus of the alkaline activator.

Sample sets 37_DVS to 41_DVS and 52_DVS to 56_DVS (Fig. 5) with quartz aggregate have the same tendency in pore distribution; the higher the silicate modulus, the higher the pore volume with a smaller diameter. If we compare the cumulative pore volume in both sets, the cumulative pore volume in the set 37 DVS to 41 DVS is lower $\left(0.08\right.$ to $\left.0.09 \mathrm{~cm}^{3} / \mathrm{g}\right)$ than in the set 52_DVS to 56_DVS ( 0.1 to $0.14 \mathrm{~cm}^{3} / \mathrm{g}$ ). This difference is the cause of higher compressive strength in the first set of samples (37_DVS to 41_DVS), in flexural tensile strength the differences are negligible. The sample 52_DVS has a lower cumulative pore volume but the proportion of the largest pores in the range of 10 to $70 \mu \mathrm{m}$ is the highest.
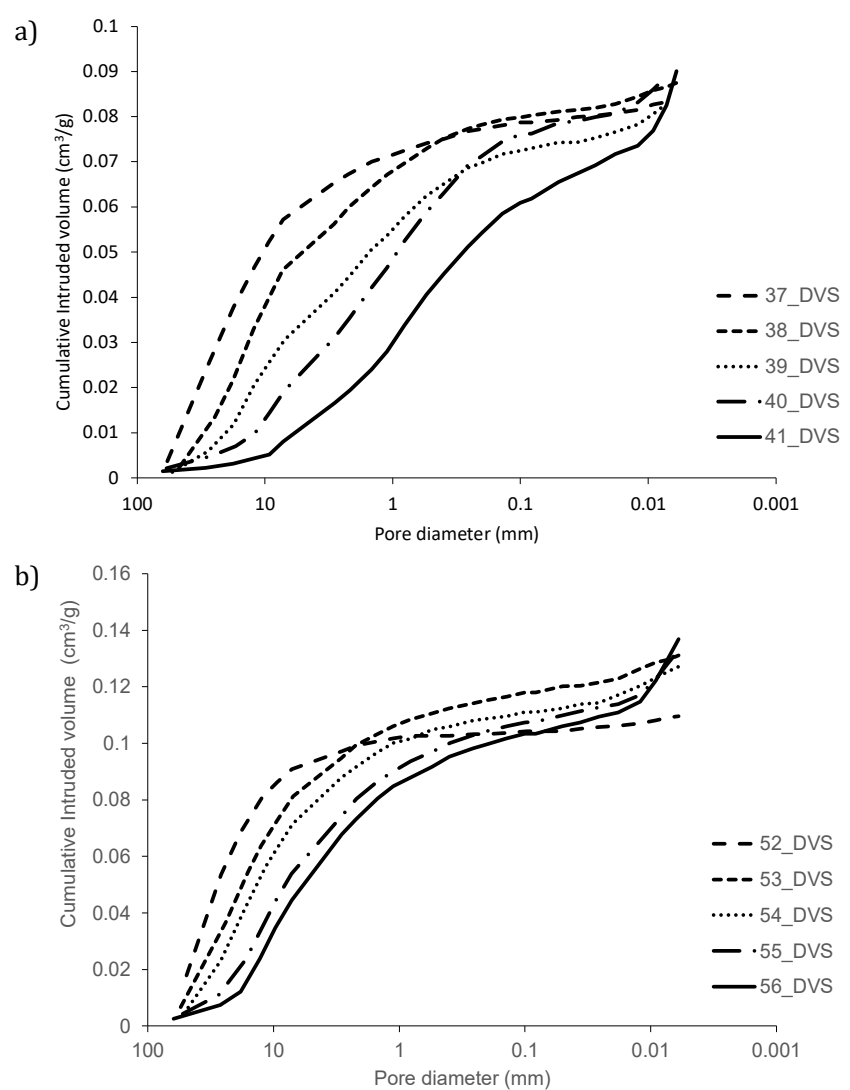

Fig. 5. Cumulative intruded volume of composites with quartz sand and grain size of brick powder: a) $0 \div 1 \mathrm{~mm}$, b) $0 \div 0.3 \mathrm{~mm}$ 
The cumulative pore volume corresponds to the strengths in the set of samples marked 42_DVS to 46_DVS (Fig. 6a) with aggregate of brick rubble. Samples 42_DVS to 44_DVS have a significantly lower cumulative pore volume compared to samples 45_DVS and 46_DVS, which ultimately leads to higher strengths.

The cumulative pore volume of the samples set 47_DVS to 51_DVS is presented in Figure 6b. The samples marked 48_DVS to 51_DVS have the same cumulative pore volume which was reflected in similar values of compressive strength. Sample 47_DVS contains more pores up to $10 \mu \mathrm{m}$ which affect the lower strength. All samples show a large volume of gel pores that relates to the grain size of the precursor in range $0 \div 0.3 \mathrm{~mm}$.

Comparing the cumulative pore volume in both sets, the cumulative pore volume in the set 42_DVS to 46_DVS is lower $\left(0.15\right.$ to $0.2 \mathrm{~cm}^{3} / \mathrm{g}$ ) than in the set 47 DVS to 51_DVS (0.2 to $0.25 \mathrm{~cm}^{3} / \mathrm{g}$ ). These differences cause the higher compressive strength in the first set of samples (42_DVS to 46_DVS).
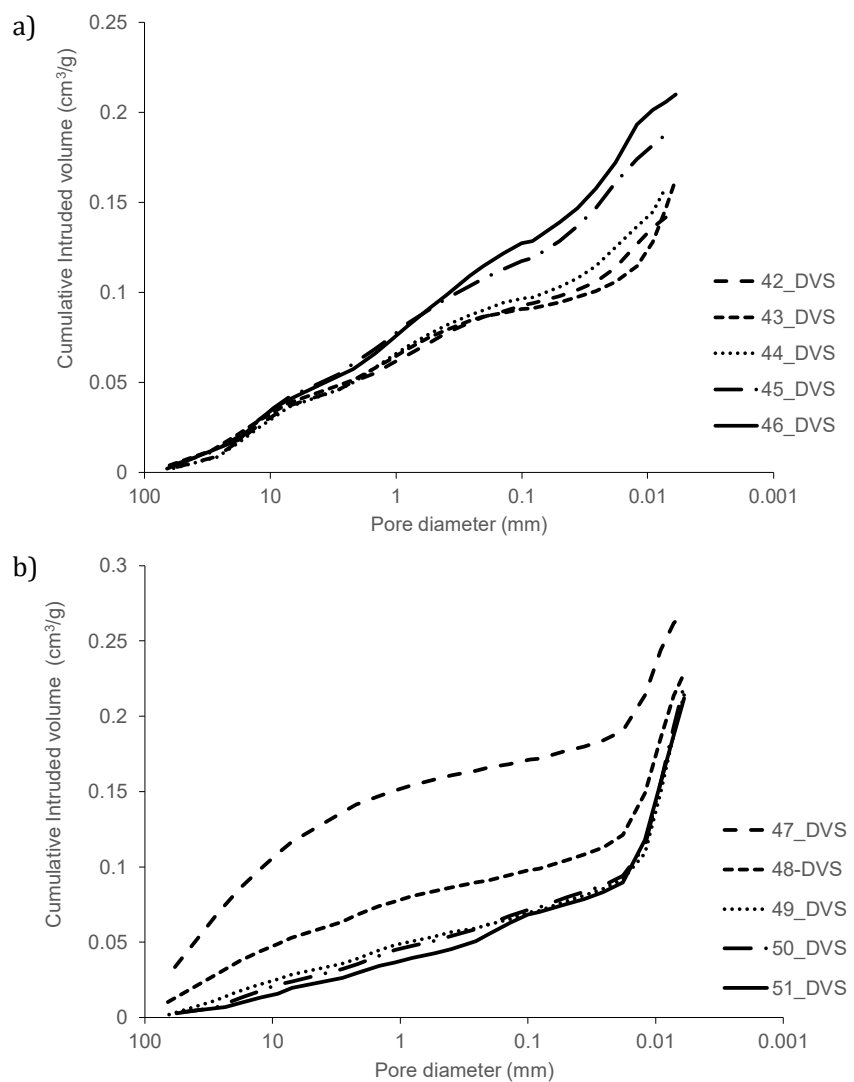

Fig. 6. Cumulative intruded volume of composites with brick rubble and grain size of brick powder:

$$
\text { a) } 0 \div 1 \mathrm{~mm} \text {,b) } 0 \div 0.3 \mathrm{~mm}
$$

The samples with $0 \div 1 \mathrm{~mm}$ grain size of precursor having the highest compressive strength present the cumulative pore diameter lower (about $25 \%$ ) compared to samples with $0 \div 0.3 \mathrm{~mm}$ grain size of precursor.

There are two groups of thermogravimetric (TG) curves in Figure 7a, for composites with precursor of grain size $0 \div 1 \mathrm{~mm}$. The upper group of curves represents samples with quartz sand, the underlying group of samples has brick rubble as an aggregate.

The curves in Figure $7 \mathrm{~b}$ represent samples with a precursor of $0 \div 0.3 \mathrm{~mm}$, the upper group of samples contains quartz sand, the lower group has brick rubble as an aggregate. 
a) 101

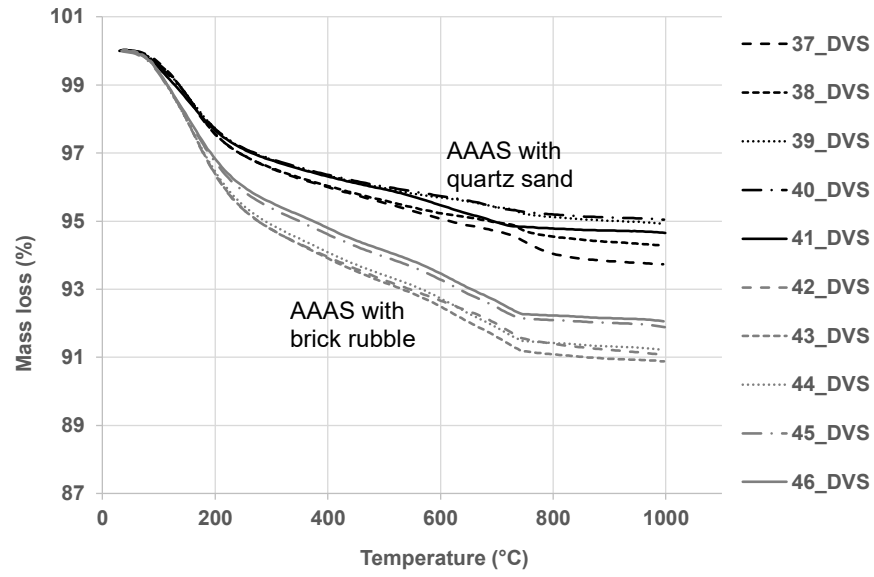

b)

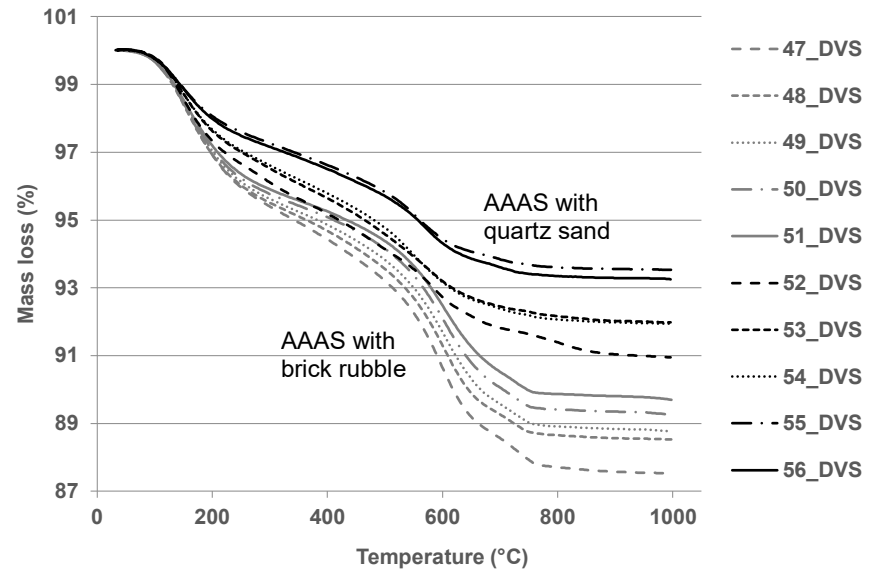

Fig. 7. Thermogravimetric curves: a) precursor $0 \div 1 \mathrm{~mm}$, b) precursor $0 \div 0.3 \mathrm{~mm}$

According to Negris [35], the weight loss on the TG curve corresponds to loss of water. It occurs in two forms:

- hygroscopic water (up to $120^{\circ} \mathrm{C}$ )

- water closely physically bound in the matrix structure $\left(120 \div 300^{\circ} \mathrm{C}\right)$.

The second type of water can be divided into three varieties:

- crystallization water $\left(120 \div 200^{\circ} \mathrm{C}\right)$

- water in hydrogels $\left(180 \div 300^{\circ} \mathrm{C}\right)$

- zeolitic water $\left(200 \div 300^{\circ} \mathrm{C}\right)$.

Chemically bound water in alkaline activation products is released in the temperature range $300 \div 750^{\circ} \mathrm{C}$. The higher temperature corresponds to the decomposition of carbonation products.

We find that brick rubble contributes significantly to the content of binder phases. Samples with brick rubble take part in the reaction with their surface, the resulting products have the same composition as the binder matrix. The higher binder content results in greater weight loss on the TG curves.

Samples with a precursor with a grain size of $0 \div 0.3 \mathrm{~mm}$ produce a larger amount of binder phases compared to a precursor with grain size $0 \div 1 \mathrm{~mm}$. This is due to the larger reaction surface of the smaller particles diameter on which the respective reactions take place.

The average values of the loss of ignition up to $1000^{\circ} \mathrm{C}$ and the loss of weight in the temperature range 105 to $700^{\circ} \mathrm{C}$ of said groups of samples are given in Table 5 . 
Table 5

Loss of ignition and amount of liberated water

\begin{tabular}{|l|l|l|l|}
\hline $\begin{array}{l}\text { Grain size of precursor } \\
(\mathrm{mm})\end{array}$ & $\begin{array}{l}\text { Loss of ignition } \\
\left(1000^{\circ} \mathrm{C}\right)(\%)\end{array}$ & $\begin{array}{l}\text { Liberatedwater } \\
120 \div 300^{\circ} \mathrm{C}(\%)\end{array}$ & $\begin{array}{l}\text { Liberatedwater } \\
300 \div 700^{\circ} \mathrm{C}(\%)\end{array}$ \\
\hline $0 \div 1$ & 5.49 & 2.89 & 1.67 \\
\hline $0 \div 1$ & 8.58 & 4.18 & 2.94 \\
\hline $0 \div 0.3$ & 11.25 & 3.98 & 6.03 \\
\hline $0 \div 0.3$ & 7.68 & 2.97 & 3.90 \\
\hline
\end{tabular}

The microstructures of all composites show cracks (Figs. 8 and 9) that are partly formed during the hardening of alkali-activated mixtures; some of the cracks are formed during the preparation of the sample for scanning in the electron microscope. Before imaging takes place, the sample is dried, and the surface is provided with a gold coating and then vacuumed under the electron microscope. These processes result in the removal of water from the gel products and the formation of the observed cracks. No artefacts of the binder phase were found on the surface of the quartz sand grains; the micrographs show the exact demarcation of the aggregate grains. The grains of quartz sand are not disturbed even by the alkaline activator solution. No significant difference was observed in the microstructure of the binder phases in the case of any of composites; the images show the compact character of the gel.

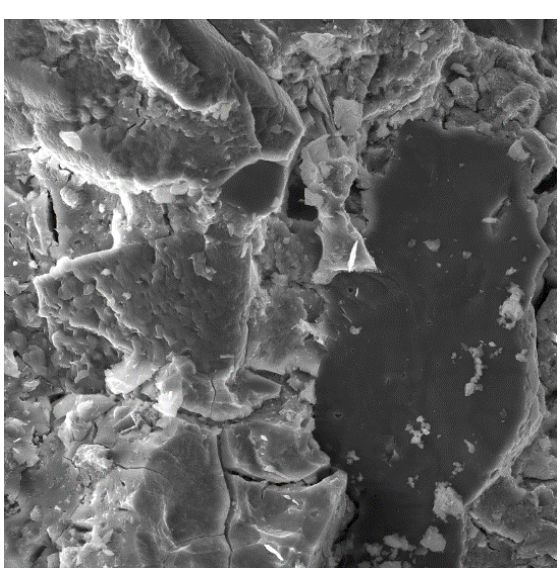

37_DVS - zoom 1000x

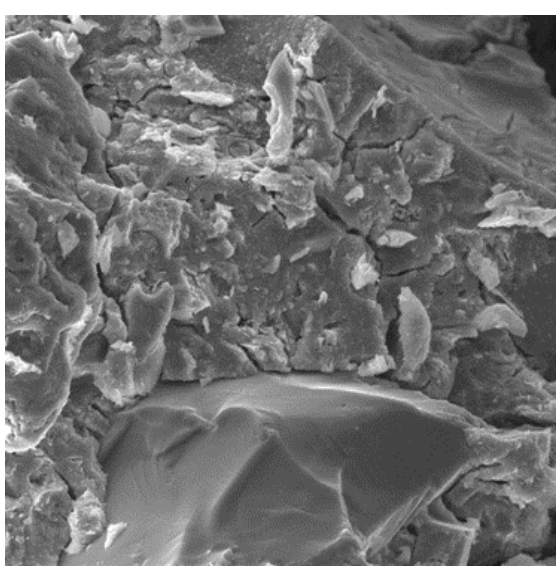

38_DVS - zoom 1000x

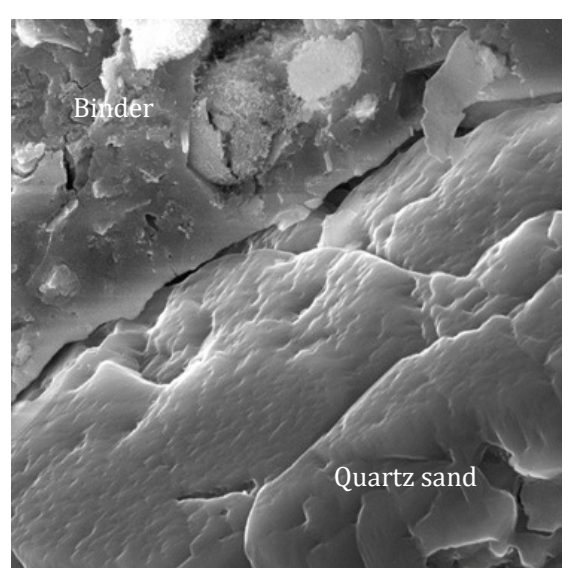

37_DVS - zoom 5000×

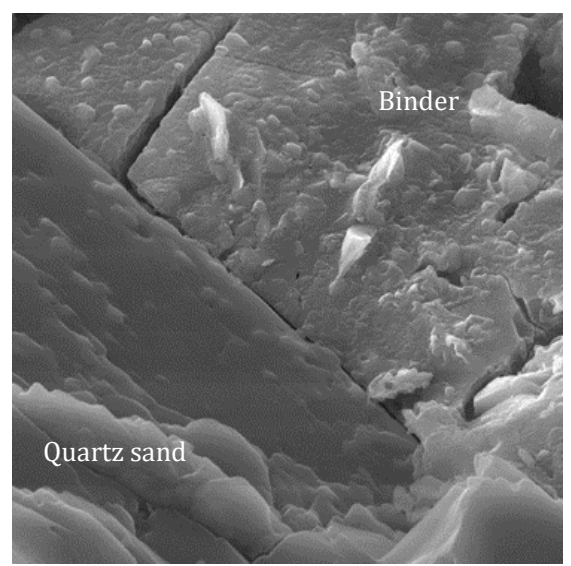

38_DVS - zoom 5000x 


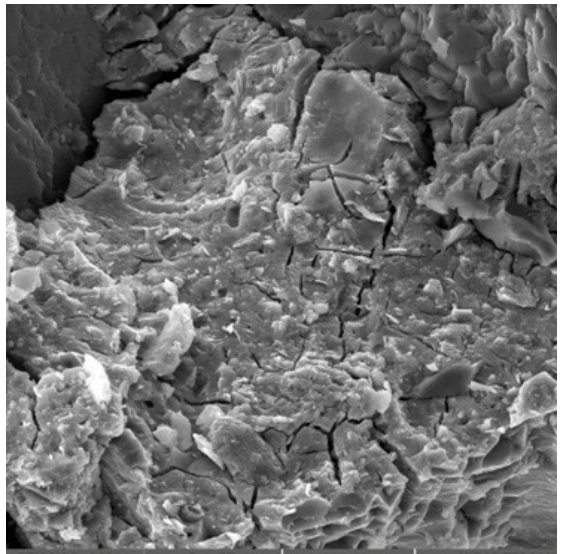

39_DVS - zoom 1000x

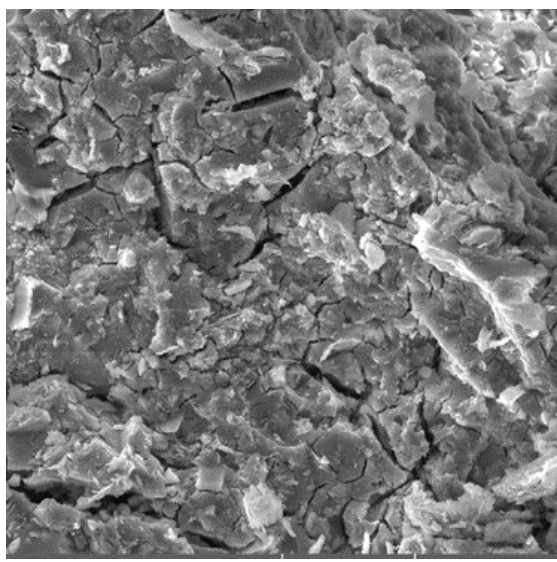

40_DVS - zoom 1000x

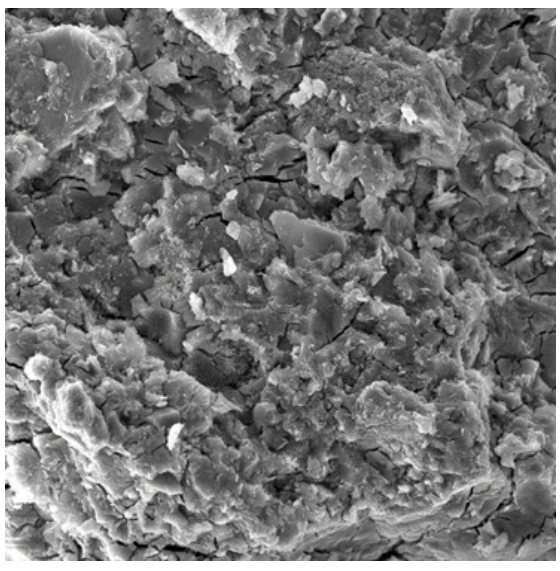

41_DVS - zoom 1000x

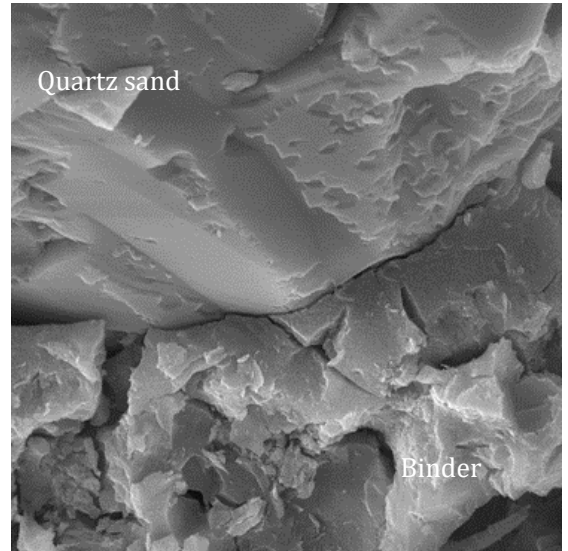

39_DVS - zoom 5000×

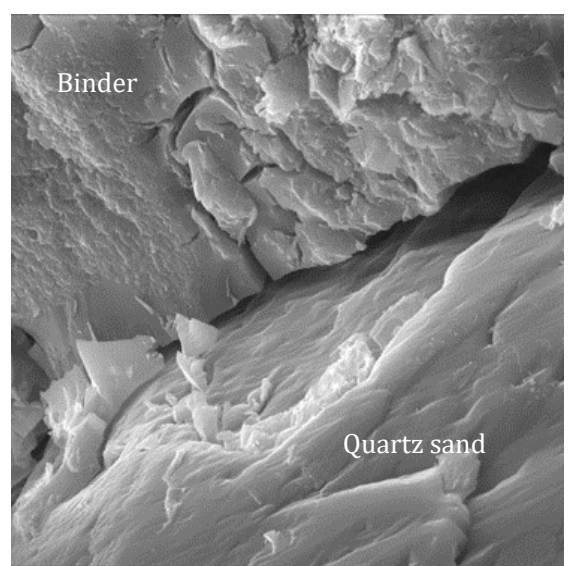

40_DVS - zoom 5000×

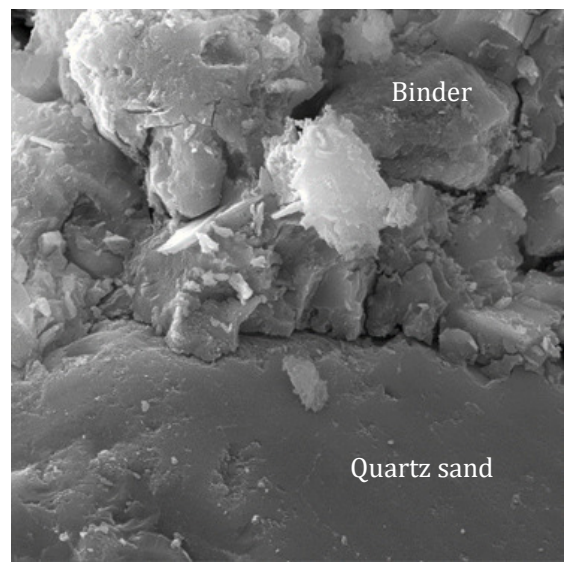

41_DVS - zoom 5000x

Fig. 8. Micrographs of composites with quartz sand and precursor $0 \div 1 \mathrm{~mm}$ 


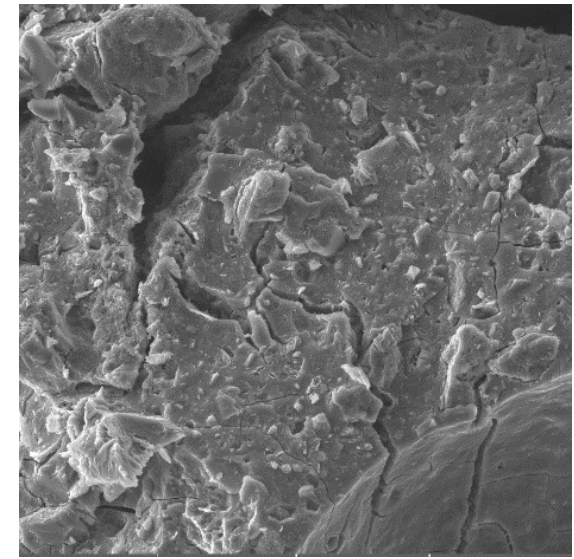

52_DVS - zoom 1000x

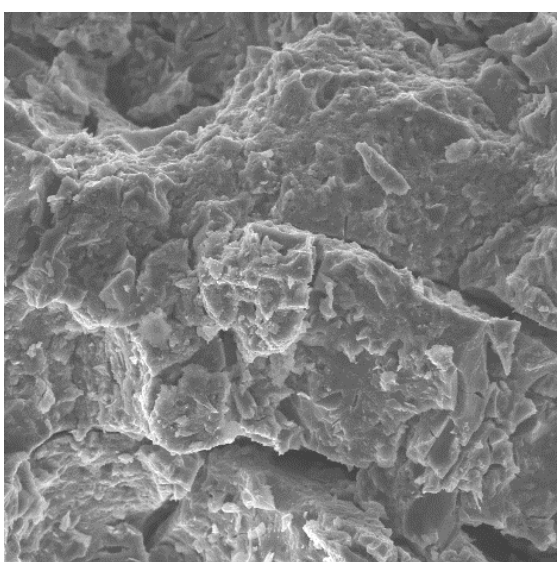

53_DVS - zoom 1000x

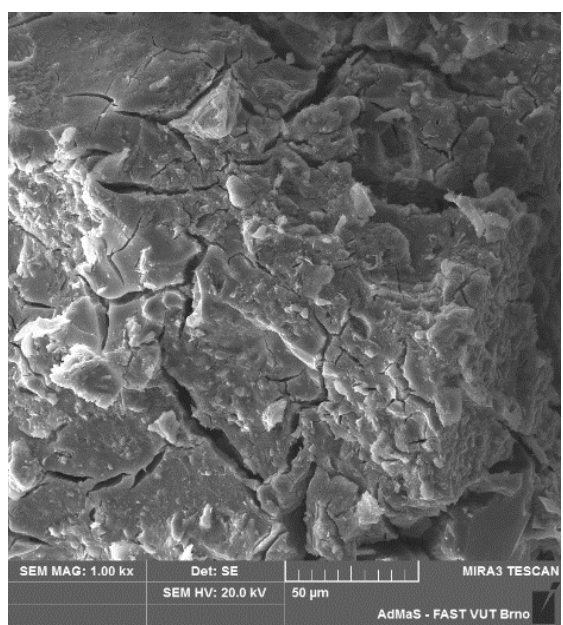

54_DVS - zoom 1000x

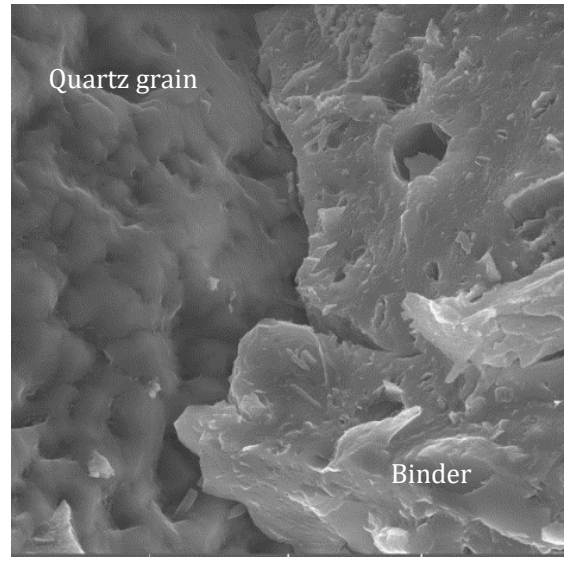

52_DVS - zoom 5000x

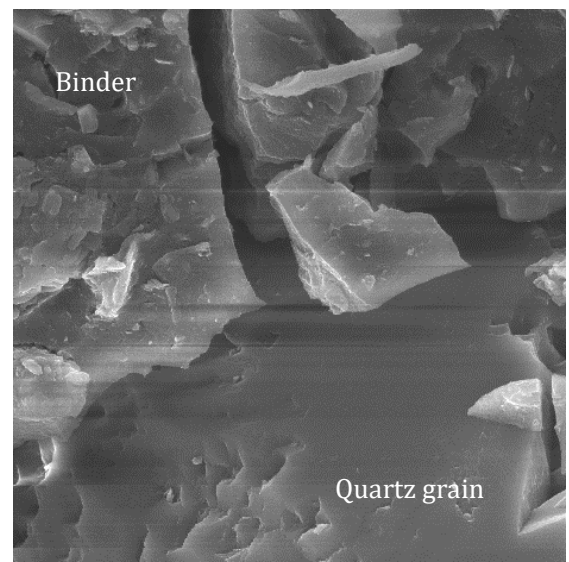

53_DVS - zoom 5000x

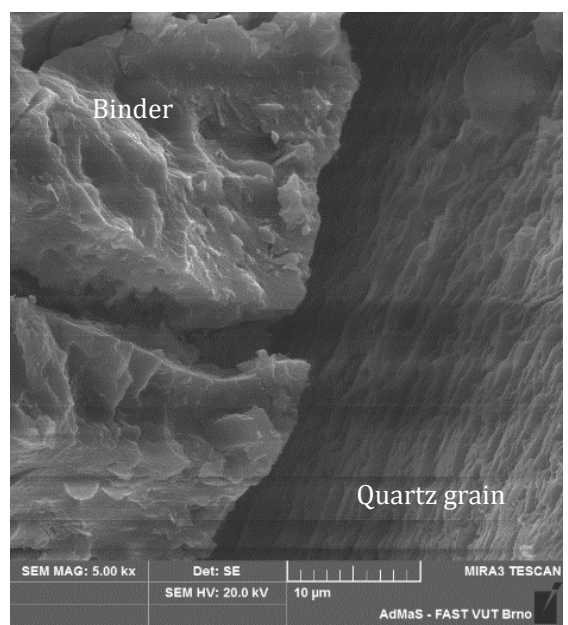

54_DVS - zoom 5000× 


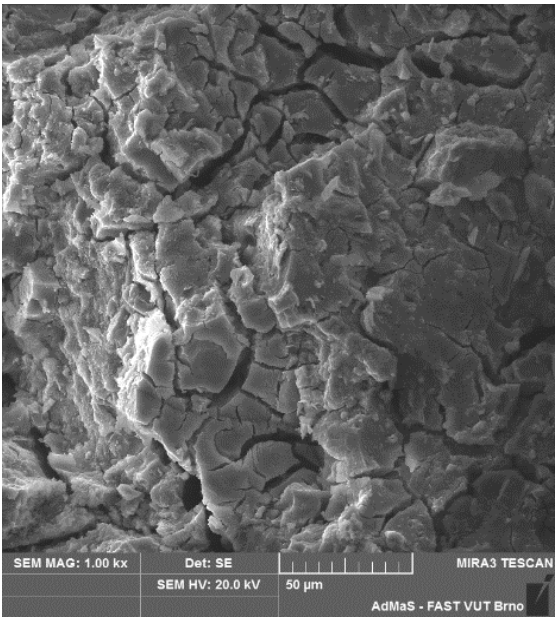

55_DVS - zoom 1000x

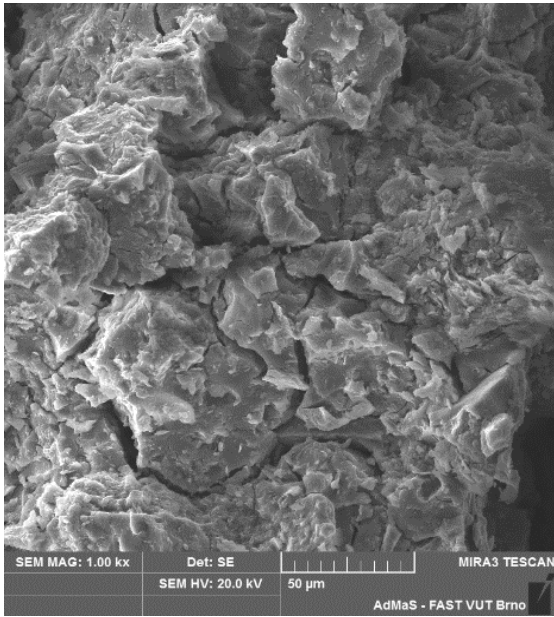

56_DVS - zoom 1000x

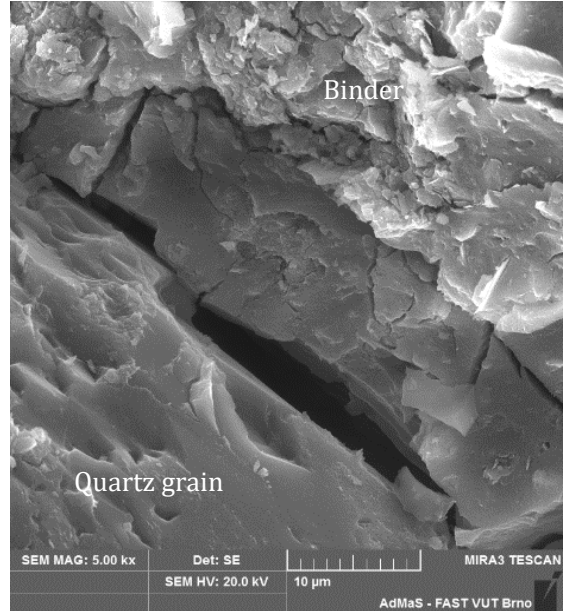

55_DVS - zoom 5000x

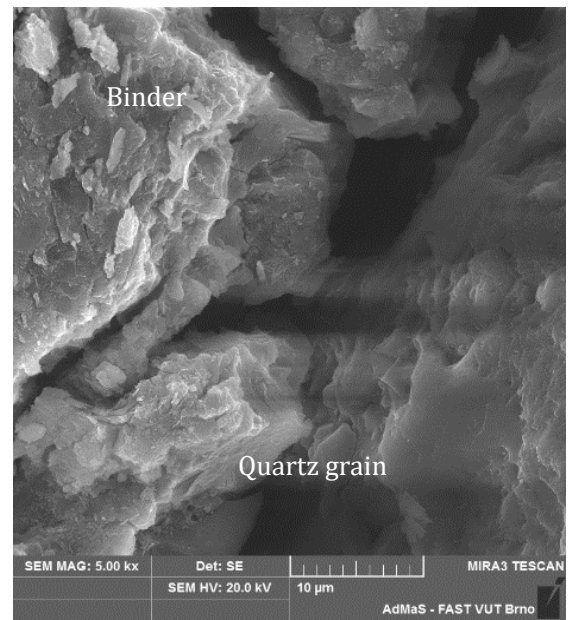

56 DVS - zoom 5000×

Fig. 9. Micrographs of composites with quartz sand and precursor $0 \div 0.3 \mathrm{~mm}$

Cracks in the binder phase also occur in composites with brick rubble (Figs. 10 and 11); they have the same origin as in the composites with quartz sand, i.e. they are formed during the formation of the binder phase and during the preparation of the samples for imaging. The binder phases in all composites with brick rubble occur in the gel form. The microstructure differs from composites with quartz sand mainly at the interface of aggregate grains and binder phases. The bonding of aggregate grains with the binder is evident here; the interface products are formed by the reaction of an alkaline activator with the surface of the grains of the brick rubble.

The measured and identified parameter values are summarized in Tables 6 and 7 . These tables include the following parameters (the subscript ID indicates an identified parameter): modulus of elasticity E, EID, compressive strength $\mathrm{fc}$, tensile strength $\mathrm{ft}$,ID, effective fracture toughness KIce, effective toughness GIc=(KIce)2/E, specific fracture energy GF, GF,ID, and characteristic length lch= GF,ID-EID/(ft,ID)2. There are also two ratios of identified to measured parameters in the tables: PEID/E for modulus of elasticity and PGF,ID/GF for fracture energy. For verification, the values were used in the numerical simulation of the fracture tests conducted on all AAAS specimens. The resulting force vs. deflection diagrams are shown in Figure 12. From the comparison with the experimental diagrams (see Fig. 1) it can be stated that very good agreement was obtained for all groups of specimens. 


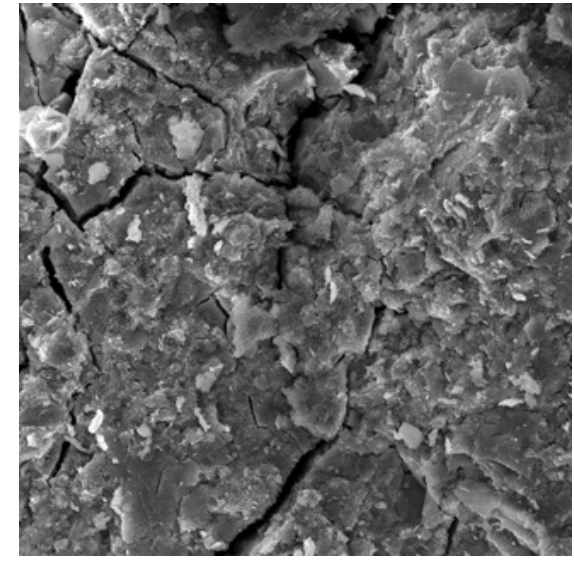

42_DVS - zoom 1000x

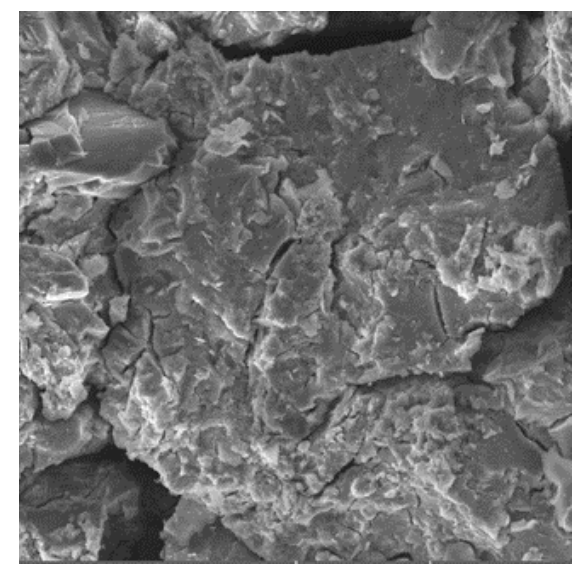

43_DVS - zoom 1000x

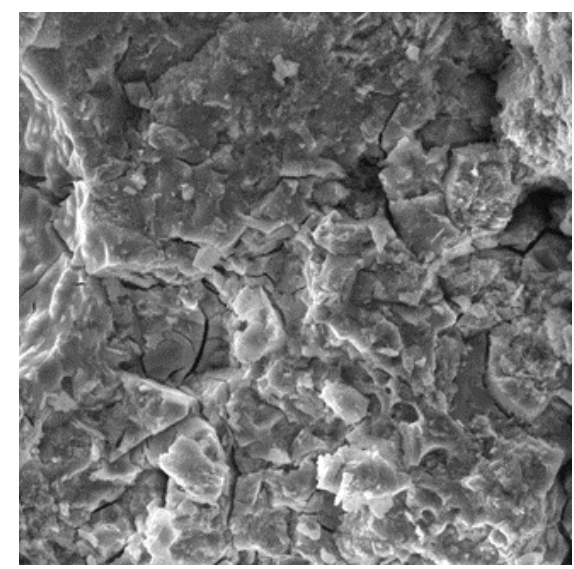

44_DVS - zoom 1000x

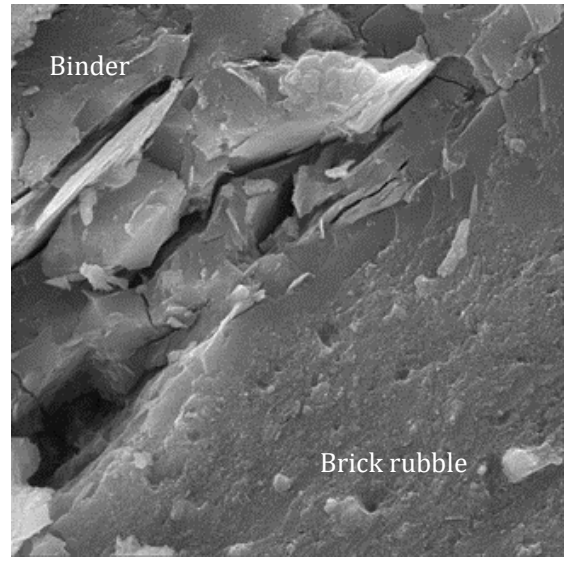

42_DVS - zoom 5000x

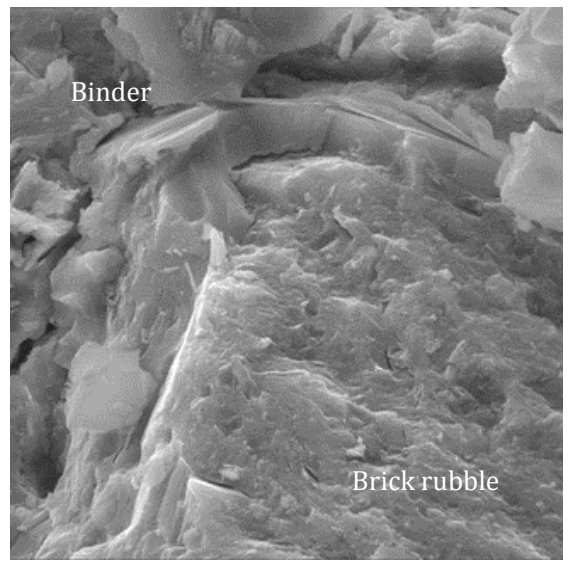

43_DVS - zoom 5000x

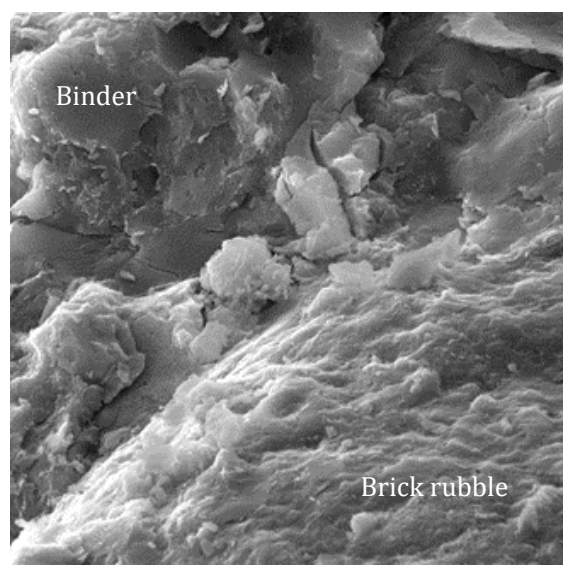

44_DVS - zoom 5000x 


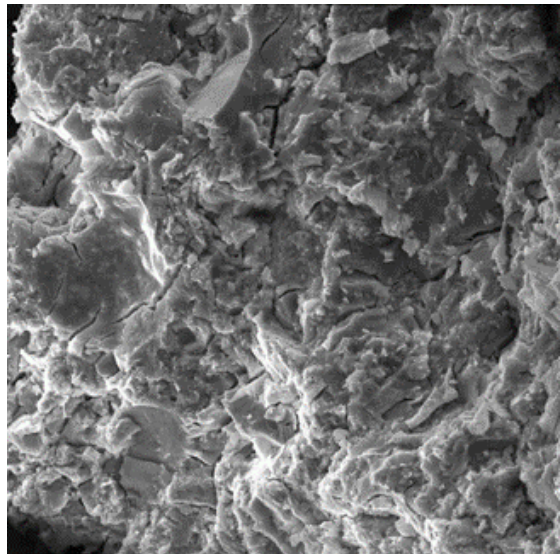

45_DVS - zoom 1000x

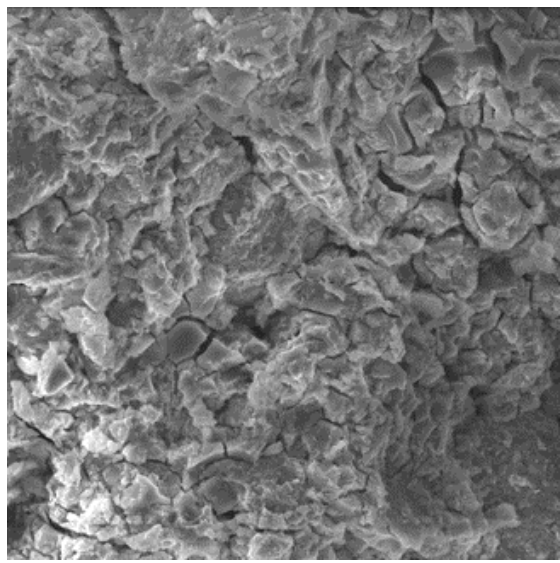

46_DVS - zoom 1000x

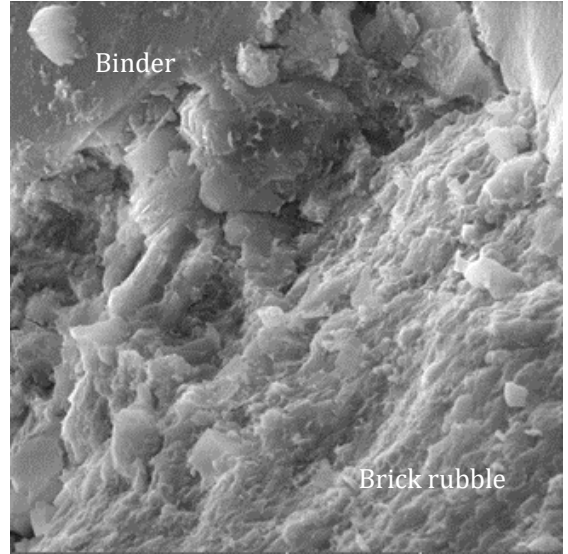

45_DVS - zoom 5000x

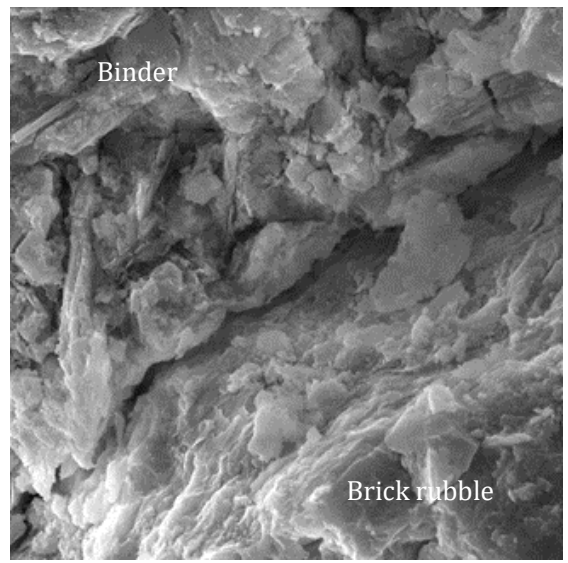

46_DVS - zoom 5000×

Fig. 10. Micrographs of composites with brick rubble and precursor $0 \div 1 \mathrm{~mm}$

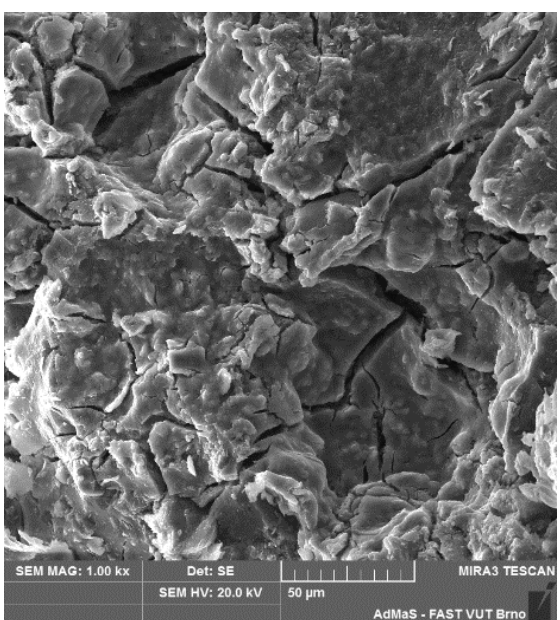

47_DVS - zoom 1000x

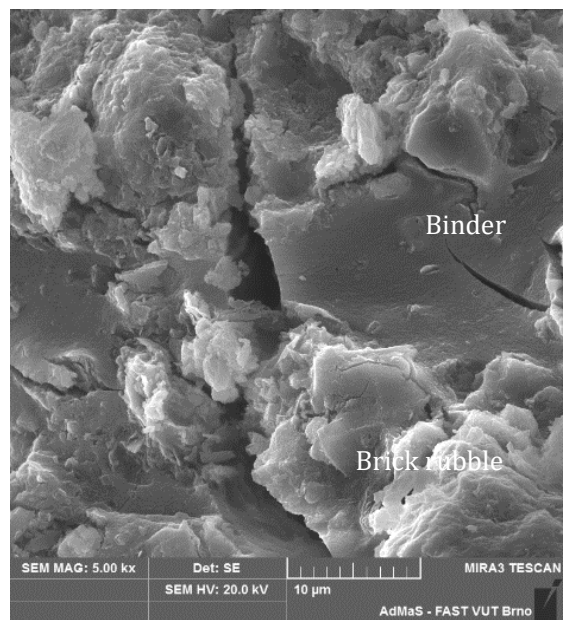

47_DVS - zoom 5000× 


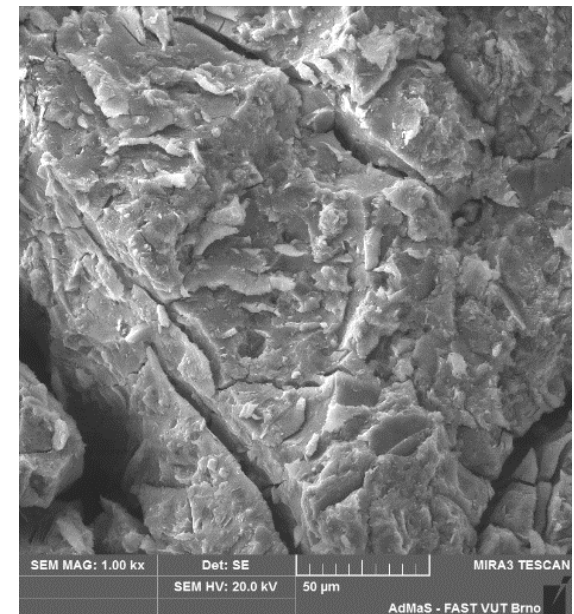

48_DVS - zoom 1000x

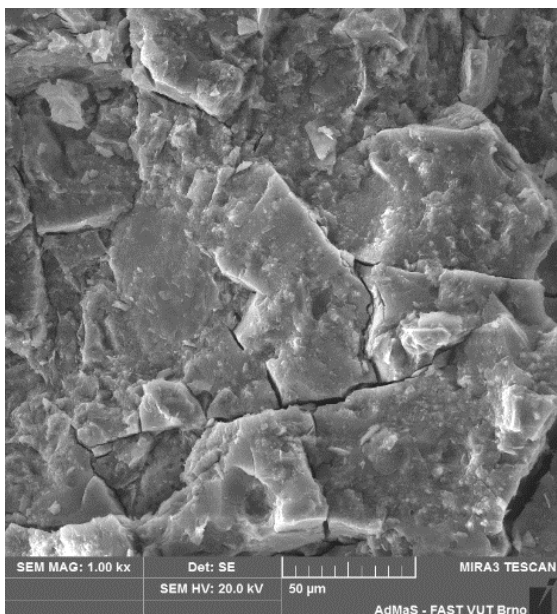

49_DVS - zoom 1000x

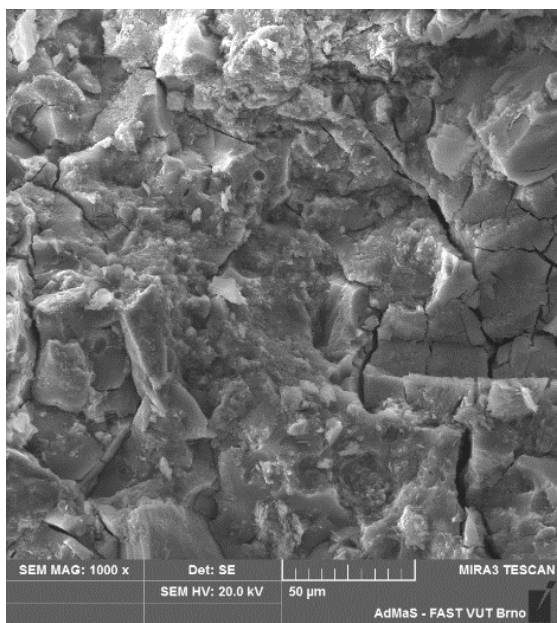

50 DVS - zoom 1000x

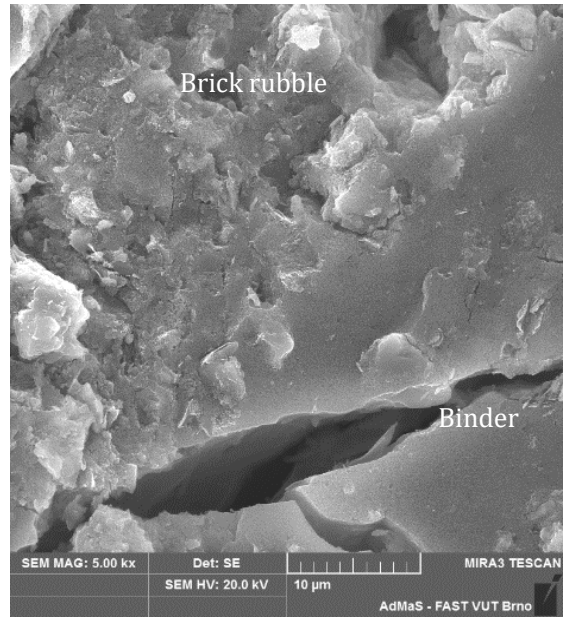

48_DVS - zoom 5000x

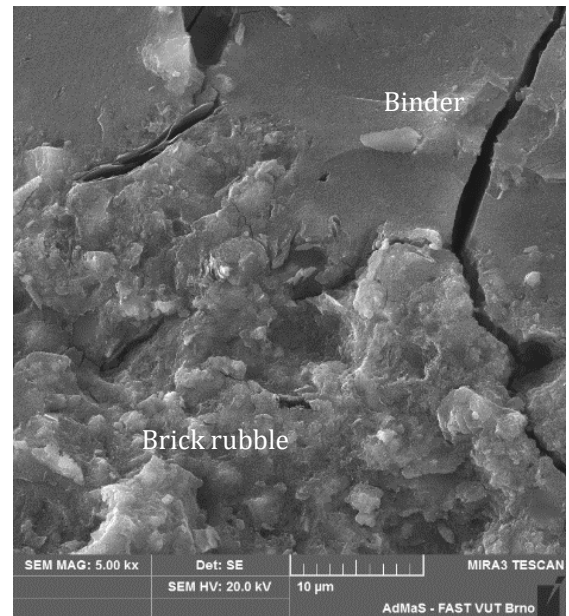

49_DVS - zoom 5000x

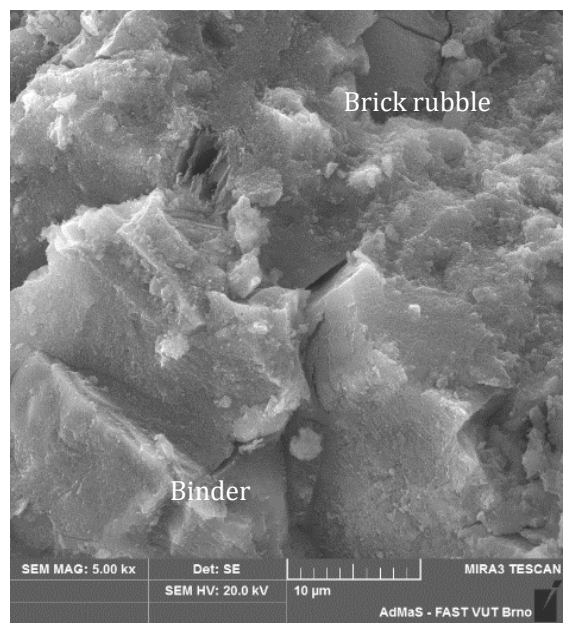

50_DVS - zoom 5000x 

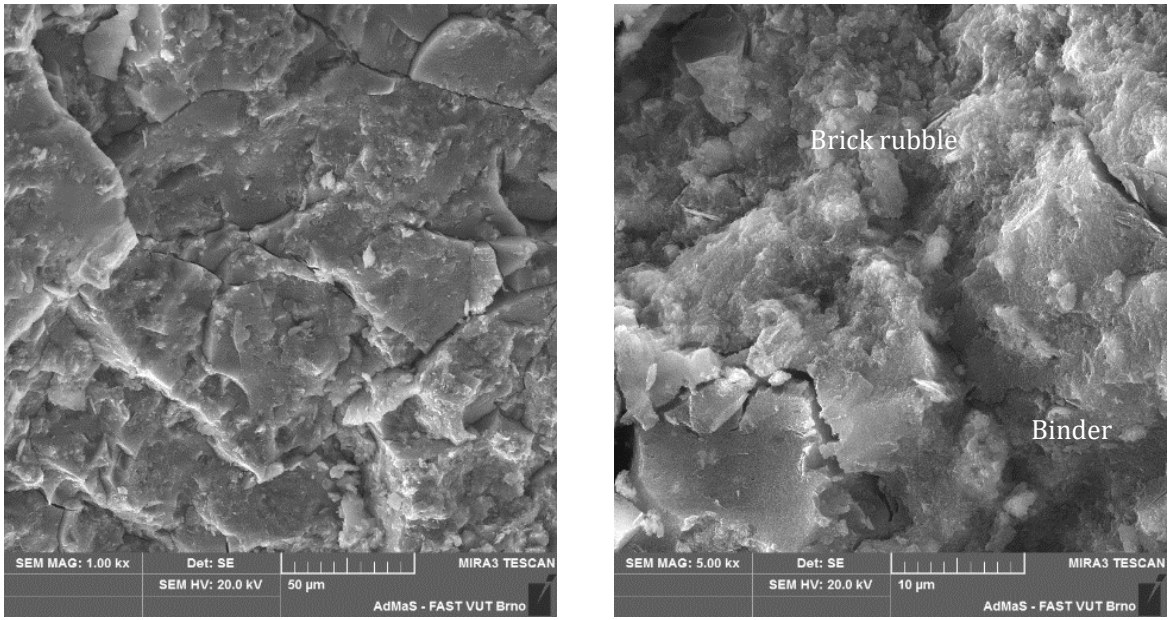

51_DVS - zoom 1000x

51_DVS - zoom 5000×

Fig. 11. Micrographs of composites with brick rubble and precursor $0 \div 0.3 \mathrm{~mm}$
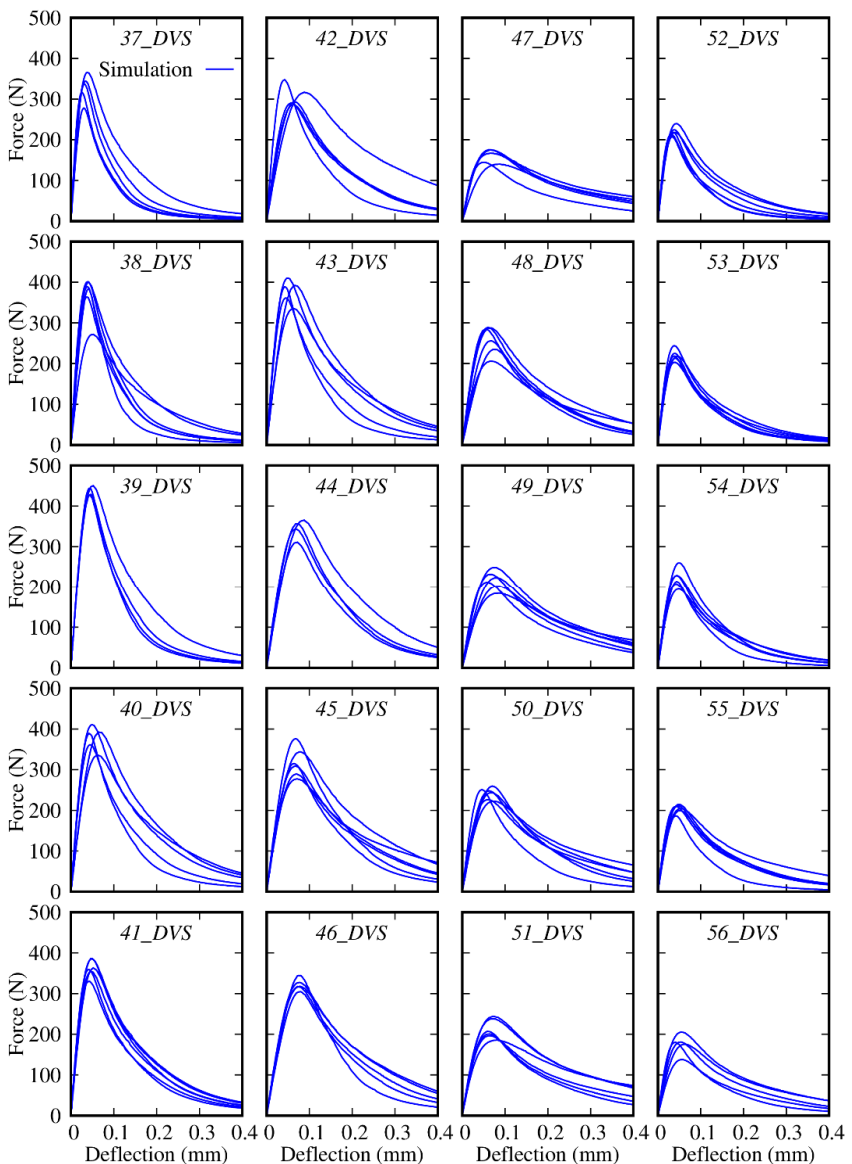

Fig. 12. Force vs. midspan deflection diagrams obtained from the fracture test simulations with identified parameters 
Table 6

Arithmetic means (coefficients of variation in \%) of mechanical fracture parameters obtained from fracture tests and inverse analyses

\begin{tabular}{|c|c|c|c|c|c|}
\hline Parameter & E & EID & PEID/E & fc & $\mathrm{ft}, \mathrm{ID}$ \\
\hline Unit & [GPa] & [GPa] & {$[\%]$} & {$[\mathrm{MPa}]$} & {$[\mathrm{MPa}]$} \\
\hline Set/Method & TEST & ID & - & TEST & ID \\
\hline 37_DVS & $8.91(6.1)$ & $\begin{array}{l}10.02 \\
(13.6)\end{array}$ & 112.5 & $30.4(9.5)$ & $\begin{array}{l}1.64 \\
(7.9)\end{array}$ \\
\hline 38_DVS & $8.23(10.3)$ & $\begin{array}{l}8.56 \\
(20.1)\end{array}$ & 104.0 & $33.1(9.4)$ & $\begin{array}{l}1.99 \\
(24.0)\end{array}$ \\
\hline 39_DVS & $7.24(7.4)$ & $\begin{array}{l}8.57 \\
(1.7)\end{array}$ & 118.4 & $31.3(9.3)$ & $\begin{array}{l}2.43 \\
(7.2)\end{array}$ \\
\hline 40_DVS & $6.64(7.2)$ & $\begin{array}{l}7.04 \\
(21.7)\end{array}$ & 106.0 & $26.9(7.0)$ & $\begin{array}{l}1.90 \\
(11.8)\end{array}$ \\
\hline 41_DVS & $6.72(4.5)$ & $\begin{array}{l}7.84 \\
(7.8)\end{array}$ & 116.7 & $26.5(15.4)$ & $\begin{array}{l}1.72 \\
(7.6)\end{array}$ \\
\hline 42_DVS & 3.69 (12.5) & $\begin{array}{l}5.01 \\
(35.7)\end{array}$ & 135.8 & $20.6(5.7)$ & $\begin{array}{l}1.53 \\
(8.7)\end{array}$ \\
\hline 43_DVS & $4.98(4.3)$ & $\begin{array}{l}5.47 \\
(7.6)\end{array}$ & 109.8 & $28.2(4.1)$ & $\begin{array}{l}2.31 \\
(16.5)\end{array}$ \\
\hline 44_DVS & $3.74(7.8)$ & $\begin{array}{l}4.11 \\
(8.8)\end{array}$ & 109.9 & $20.4(5.2)$ & $\begin{array}{l}1.99 \\
(8.3)\end{array}$ \\
\hline 45_DVS & $3.56(8.8)$ & $\begin{array}{l}4.39 \\
(6.6)\end{array}$ & 123.3 & $21.7(6.0)$ & $\begin{array}{l}1.62 \\
(20.1)\end{array}$ \\
\hline 46_DVS & $3.46(14.0)$ & $\begin{array}{l}3.80 \\
(7.2)\end{array}$ & 109.8 & $18.0(15.0)$ & $\begin{array}{l}1.82 \\
(19.2)\end{array}$ \\
\hline 47_DVS & 2.39 (17.3) & $\begin{array}{l}3.00 \\
(20.0)\end{array}$ & 125.5 & 7.7 (16.4) & $\begin{array}{l}0.65 \\
(12.4)\end{array}$ \\
\hline 48_DVS & $3.45(18.0)$ & $\begin{array}{l}4.05 \\
(21.3)\end{array}$ & 117.4 & $16.8(9.3)$ & $\begin{array}{l}1.25 \\
(15.4)\end{array}$ \\
\hline 49_DVS & 2.99 (19.3) & $\begin{array}{l}3.19 \\
(18.9)\end{array}$ & 106.7 & $15.1(7.6)$ & $\begin{array}{l}0.97 \\
(14.2)\end{array}$ \\
\hline 50_DVS & $3.71(9.1)$ & $\begin{array}{l}3.97 \\
(17.9)\end{array}$ & 107.0 & $17.2(6.8)$ & $\begin{array}{l}1.15 \\
(16.2)\end{array}$ \\
\hline 51_DVS & $2.91(9.0)$ & $\begin{array}{l}3.51 \\
(7.4)\end{array}$ & 120.7 & $13.9(6.9)$ & $\begin{array}{l}0.91 \\
(14.0)\end{array}$ \\
\hline 52_DVS & $5.08(10.5)$ & $6.15(9.8)$ & 121.1 & $17.6(7.8)$ & $1.03(8.0)$ \\
\hline 53_DVS & $4.54(10.8)$ & $5.63(9.2)$ & 124.0 & $16.4(4.5)$ & $1.03(8.4)$ \\
\hline 54_DVS & $4.04(8.7)$ & $4.86(9.3)$ & 120.3 & $15.3(5.9)$ & 1.09 (16.7) \\
\hline 55_DVS & 3.91 (11.4) & $4.50(12.1)$ & 115.2 & $12.7(9.5)$ & $0.94(7.0)$ \\
\hline 56_DVS & 3.03 (19.6) & 3.64 (22.9) & 120.2 & $11.3(6.8)$ & $0.78(12.0)$ \\
\hline
\end{tabular}


Table 7

Arithmetic means (coefficients of variation in \%) of mechanical fracture parameters obtained from fracture tests and inverse analyses

\begin{tabular}{|c|c|c|c|c|c|c|}
\hline Parameter & KIce & GIce & $\mathrm{GF}$ & GF,ID & PGF,ID/GF & lch \\
\hline Unit & {$\left[\mathrm{MPa} \cdot \mathrm{m}^{1 / 2}\right]$} & {$\left[\mathrm{N} \cdot \mathrm{m}^{-1}\right]$} & {$\left[\mathrm{J} \cdot \mathrm{m}^{-2}\right]$} & {$\left[\mathrm{J} \cdot \mathrm{m}^{-2}\right]$} & [\%] & {$[\mathrm{mm}]$} \\
\hline Set/Method & TEST & TEST & TEST & ID & - & ID \\
\hline 37_DVS & $0.309(9.0)$ & $10.8(20.7)$ & $31.1(16.6)$ & $\begin{array}{l}34.4 \\
(29.8)\end{array}$ & 110.6 & $\begin{array}{l}127.2 \\
(24.1)\end{array}$ \\
\hline 38_DVS & 0.339 (11.7) & $14.9(19.8)$ & 43.5 (18.7) & $\begin{array}{l}45.5 \\
(20.3)\end{array}$ & 104.6 & $\begin{array}{l}117.5 \\
(57.6)\end{array}$ \\
\hline 39_DVS & $0.385(1.0)$ & $20.6(9.4)$ & $55.3(20.6)$ & $\begin{array}{l}56.2 \\
(19.5) \\
\end{array}$ & 101.6 & $\begin{array}{l}83.7 \\
(31.7) \\
\end{array}$ \\
\hline 40_DVS & $0.354(9.4)$ & $22.7(16.0)$ & $60.9(15.0)$ & $\begin{array}{l}64.1 \\
(20.9)\end{array}$ & 105.3 & $\begin{array}{l}125.8 \\
(28.2)\end{array}$ \\
\hline 41_DVS & $0.353(8.0)$ & $18.7(18.3)$ & $53.4(20.3)$ & $\begin{array}{l}58.9 \\
(11.3)\end{array}$ & 110.3 & $\begin{array}{l}156.9 \\
(12.8)\end{array}$ \\
\hline 42_DVS & 0.299 (11.3) & $18.8(19.4)$ & $62.0(26.5)$ & $\begin{array}{l}61.7 \\
(30.2) \\
\end{array}$ & 99.5 & $\begin{array}{l}123.6 \\
(15.6)\end{array}$ \\
\hline 43_DVS & $0.356(3.4)$ & $25.5(6.5)$ & $70.4(7.5)$ & $\begin{array}{l}65.5 \\
(14.0) \\
\end{array}$ & 93.0 & $\begin{array}{l}72.0 \\
(38.4) \\
\end{array}$ \\
\hline 44_DVS & $0.338(9.0)$ & 30.8 (19.9) & 71.0 (17.5) & $\begin{array}{l}66.8 \\
(16.3)\end{array}$ & 94.1 & $\begin{array}{l}69.6 \\
(14.8)\end{array}$ \\
\hline 45_DVS & $0.302(11.1)$ & $25.8(18.5)$ & $72.1(12.0)$ & $\begin{array}{l}70.5 \\
(15.9)\end{array}$ & 97.8 & $\begin{array}{l}129.9 \\
(44.7)\end{array}$ \\
\hline 46_DVS & $0.291(7.1)$ & $24.7(12.8)$ & $70.2(14.3)$ & $\begin{array}{l}68.8 \\
(14.4) \\
\end{array}$ & 98.0 & $\begin{array}{l}88.2 \\
(42.8)\end{array}$ \\
\hline 47_DVS & $0.193(14.0)$ & $16.1(25.1)$ & $51.4(17.8)$ & $\begin{array}{l}52.4 \\
(21.8) \\
\end{array}$ & 101.9 & $\begin{array}{l}384.3 \\
(38.1) \\
\end{array}$ \\
\hline 48_DVS & $0.295(16.3)$ & $25.4(21.6)$ & $58.2(11.7)$ & $\begin{array}{l}57.7 \\
(11.3)\end{array}$ & 99.1 & $\begin{array}{l}157.6 \\
(38.4)\end{array}$ \\
\hline 49_DVS & 0.254 (11.8) & $22.1(20.9)$ & $60.9(16.1)$ & $\begin{array}{l}62.0 \\
(13.0)\end{array}$ & 101.8 & $\begin{array}{l}214.1 \\
(30.1)\end{array}$ \\
\hline 50_DVS & $0.286(3.9)$ & $22.4(17.5)$ & $54.5(13.1)$ & $\begin{array}{l}54.8 \\
(20.2)\end{array}$ & 100.6 & $\begin{array}{l}177.5 \\
(43.1)\end{array}$ \\
\hline 51_DVS & 0.259 (12.8) & $23.4(22.1)$ & $59.5(17.6)$ & $\begin{array}{l}62.6 \\
(25.4) \\
\end{array}$ & 105.2 & $\begin{array}{l}284.7 \\
(45.2) \\
\end{array}$ \\
\hline 52_DVS & $0.232(11.2)$ & $10.8(23.6)$ & $27.8(28.4)$ & $29.8(23.5)$ & 107.2 & $175.9(30.2)$ \\
\hline 53_DVS & $0.225(3.9)$ & $11.2(7.6)$ & $30.7(7.4)$ & $31.9(10.0)$ & 103.7 & $170.9(21.5)$ \\
\hline 54_DVS & $0.220(13.0)$ & $12.2(24.6)$ & $32.4(10.4)$ & $34.3(13.6)$ & 106.1 & $150.8(35.5)$ \\
\hline 55_DVS & $0.220(10.0)$ & $12.5(18.3)$ & 34.0 (17.3) & $37.0(23.6)$ & 109.0 & $196.4(38.7)$ \\
\hline 56_DVS & 0.197 (18.9) & $12.8(21.3)$ & 35.5 (13.0) & $37.6(24.3)$ & 105.8 & $221.0(13.7)$ \\
\hline
\end{tabular}

\section{Conclusions}

Selected alkali-activated aluminosilicate composites based on a ceramic precursor and an alkaline activator with a variable silicate modulus and with different filler variants were characterized in terms of their mechanical fracture and microstructural parameters. The parameters obtained from the evaluation of fracture tests were suitably and effectively supple- 
mented by the identification of parameters using artificial neural networks. This maximized the number of determined parameters from a given number of fracture tests. From the above outputs and the evaluation of the tests, it can be concluded that:

The silicate modulus Ms and the type of filler added to the AAAS composites significantly affected the compressive strength, modulus of elasticity, fracture toughness and fracture energy of the material. While the first two named parameters were significantly higher for the quartz sand filler (the resulting composites were stronger and stiffer), the fracture energies reached higher values in all cases for the composites with brick rubble filler - this filler had a significant toughening effect on the studied AAAS composite. This is due to the formation of binder phases at the grain boundary of the brick rubble and the matrix. The brick rubble significantly increases the amount of binder phases in the samples.

The refinement of the precursor resulted in a significant reduction in compressive and tensile strengths, a slight reduction in fracture toughness, and a more than twofold increase in characteristic length. On the other hand, it had a negligible effect on toughness and fracture energy.

The values identified for comparable parameters by artificial neural networks were higher compared to the evaluation of the real tests by 4 to $37 \%$ in the case of the modulus of elasticity and very similar for fracture energy - the range was from -7 to $11 \%$.

Thanks to the combination of evaluation methods, tensile strength values were obtained that would otherwise require the investigation of the responses of additional specimens tested in a different test configuration. Furthermore, a relevant estimate of the length of the fracture process zone (characteristic length) was obtained.

Further work will focus on completing a series of AAAS composites with the same silicate modulus range of alkaline activators and the same type of aggregate, but using a brick precursor with higher fineness. It is planned that a similar evaluation of fracture tests using artificial neural networks will be conducted.

\section{Acknowledgement}

Financial support provided by the Czech Science Foundation (GACR) under project No. 19-09491S (MUFRAS, mainly the first and fifth author - neural network support) and No. 19-01982S (alkali-activated aluminosilicate composites based on ceramic precursors) is gratefully acknowledged. We would also like to thank Hana Štefaníková from the Institute of Chemistry at FAST BUT in Brno for the preparation of test specimens.

\section{References}

[1] Pudron A.O., The action of alkalis on blast furnace slag, Journal of the Society of Chemical Industry 1940, 59(9), 191-202.

[2] Glukhovsky V.D., Soil silicates. Kiev: Gostroiizdat Publish 1959.

[3] Davidovits J., Synthesis of new high-temperature geo-polymer for reinforced plastics/composites, SPE PACTEC 79 Society of Plastic Engineers. Costa Mesa: SPE, 1979, 151-154.

[4] Karihaloo Bhushan L., Fracture Mechanics and Structural Concrete. Essex: Longman Scientific \& Technical 1995.

[5] Veselý V., Keršner Z., Merta I., Quasi-brittle Behaviour of Composites as a Key to Generalized Understanding of Material Structure, Procedia Engineering 2017, 190, 126-133. doi: 10.1016/j.proeng.2017.05.317.

[6] Šimonová H. et al., Fracture parameters of alkali-activated aluminosilicate composites with ceramic precursor, Solid State Phenomena: 26th Concrete Days. Switzerland: Trans Tech Publications, 2020, 73-79.

[7] Glukhovsky V., Rostovskaja G., Rumyna G., High strength slag-alkaline cements, Proceedings of the seventh international congress on the chemistry of cement, 1980, 164-168.

[8] Davidovits J., Geopolymer chemistry and properties, Proceedings of the conference on Geopolymére 1988, 25-48.

[9] Palomo A., Grutzeck M.W., Blanco M.T., Alkali-activated fly ashes, Cement and Concrete Research 1999, 29(8), 1323-1329. doi: 10.1016/s0008-8846(98)00243-9.

[10] Yip C.K., Lukey G.C., van Deventer J.S.J., The coexistence of geopolymeric gel and calcium silicate hydrate at the early stage of alkaline activation, Cement and Concrete Research 2005, 35(9), 1688-1697. doi: 10.1016/ j.cemconres.2004.10.042. 
[11] Puertas F., Fernández-Jiménez A., Blanco-Varela M.T., Pore solution in alkali-activated slag cement pastes. Relation to the composition and structure of calcium silicate hydrate, Cement and Concrete Research 2004, 34(1), 139-148. doi: 10.1016/s0008-8846(03)00254-0.

[12] Fernández-Jiménez A., Palomo A., Characterisation of fly ashes. Potential reactivity as alkaline cements, Fuel 2003, 82(18), 2259-2265. doi: 10.1016/s0016-2361(03)00194-7.

[13] Robayo R.A. et al., Alternative cements based on alkali-activated red clay brick waste, Construction and Building Materials 2016, 128, 163-169. doi: 10.1016/j.conbuildmat.2016.10.023.

[14] Reig L. et al., Properties and microstructure of alkali-activated red clay brick waste, Construction and Building Materials 2013, 43, 98-106. doi: 10.1016/j.conbuildmat.2013.01.031.

[15] Reig L. et al., Influence of the activator concentration and calcium hydroxide addition on the properties of alkali-activated porcelain stoneware, Construction and Building Materials 2014, 63, 214-222. doi: 10.1016/ j.conbuildmat.2014.04.023.

[16] Tuyan M., Andiç-Çakir Ö., Ramyar K., Effect of alkali activator concentration and curing condition on strength and microstructure of waste clay brick powder-based geopolymer, Composites Part B: Engineering 2018, 135, 242-252. doi: 10.1016/j.compositesb.2017.10.013.

[17] Sun Z. et al., Synthesis and thermal behavior of geopolymer-type material from waste ceramic, Construction and Building Materials 2013, 49, 281-287. doi: 10.1016/j.conbuildmat.2013.08.063.

[18] Komnitsas K. et al., Effect of synthesis parameters on the quality of construction and demolition wastes (CDW) geopolymers, Advanced Powder Technology 2015, 26(2), 368-376. doi: 10.1016/j.apt.2014.11.012.

[19] Komnitsas K., Zaharaki D., Geopolymerisation: A review and prospects for the minerals industry, Minerals Engineering 2007, 20(14), 1261-1277. doi: 10.1016/j.mineng.2007.07.011.

[20] Fořt J. et al., Application of waste brick powder in alkali activated aluminosilicates: Functional and environmental aspects, Journal of Cleaner Production 2018, 194, 714-725. doi: 10.1016/j.jclepro.2018.05.181.

[21] Karozou A. et al., Alkali activated clay mortars with different activators, Construction and Building Materials 2019, 212, 85-91. doi: 10.1016/j.conbuildmat.2019.03.244.

[22] Mohammadinia A. et al., Impact of potassium cations on the light chemical stabilization of construction and demolition wastes, Construction and Building Materials 2019, 203, 69-74. doi: 10.1016/j.conbuildmat.2019. 01.083.

[23] Kaewmee P. et al., Porous and reusable potassium-activated geopolymer adsorbent with high compressive strength fabricated from coal fly ash wastes, Journal of Cleaner Production 2020, 272, p. 122617. doi: 10.1016/j.jclepro.2020.122617.

[24] Gavali H.R. et al., Development of sustainable alkali-activated bricks using industrial wastes, Construction and Building Materials 2019, 215, 180-191. doi: 10.1016/j.conbuildmat.2019.04.152.

[25] Lee N. et al., Alkali-activated, cementless, controlled low-strength materials (CLSM) utilizing industrial byproducts, Construction and Building Materials 2013, 49, 738-746. doi: 10.1016/j.conbuildmat.2013.09.002.

[26] Shekhovtsova J. et al., Estimation of fly ash reactivity for use in alkali-activated cements - A step towards sustainable building material and waste utilization, Journal of Cleaner Production 2018, 178, 22-33. doi: 10.1016/j.jclepro.2017.12.270.

[27] De Silva P., Sagoe-Crenstil K., Sirivivatnanon V., Kinetics of geopolymerization: Role of Al2O3 and SiO2, Cement and Concrete Research 2007, 37(4), 512-518. doi: 10.1016/j.cemconres.2007.01.003.

[28] Pacheco-Torgal F., Castro-Gomes J., Jalali S., Alkali-activated binders: A review. Part 2. About materials and binders manufacture, Construction and Building Materials 2008, 22(7), 1315-1322. doi: 10.1016/ j.conbuildmat.2007.03.019.

[29] Fernández-Jiménez A., Palomo A., Composition and microstructure of alkali activated fly ash binder: Effect of the activator, Cement and Concrete Research 2005, 35(10), 1984-1992. doi: 10.1016/j.cemconres.2005.03.003.

[30] RILEM TC-50 FMC Determination of the fracture energy of mortar and concrete by means of three-point bend tests on notched beams, Materials and Structures 1985, 18(106), 285-290.

[31] Novák D., Lehký D., ANN inverse analysis based on stochastic small-sample training set simulation, Engineering Applications of Artificial Intelligence 2006, 19(7), 731-740. doi: 10.1016/j.engappai.2006.05.003.

[32] Lehký D., Keršner Z., Novák D., FraMePID-3PB software for material parameter identification using fracture tests and inverse analysis, Advances in Engineering Software 2014, 72, 147-154. doi: 10.1016/j.advengsoft. 2013.10.001.

[33] Červenka V., Jendele L., Červenka J., ATENA program documentation Part 1: theory. Cervenka Consulting Ltd., Prague 2016

[34] Lehký D. et al., A neural network ensemble for the identification of mechanical fracture parameters of finegrained brittle matrix composites, Proceedings of the 10th International Conference on Fracture Mechanics of Concrete and Concrete Structures. Bayonne: 2019, FraMCoS X. doi: 10.21012/fc10.234717.

[35] Nergis D.D.B. et al., XRD and TG-DTA study of new alkali activated materials based on fly ash with sand and glass powder, Materials 2020, 13(2), 343. doi: 10.3390/ma13020343. 


\section{Pękanie mechaniczne i parametry mikrostrukturalne materiałów aktywowanych alkaliami z ceramicznym prekursorem}

\section{STRESZCZENIE:}

Przebadano cztery zestawy kompozytów glinokrzemianowych aktywowanych alkaliami na bazie prekursorów ceramicznych pod kątem ich charakterystyki, pękania mechanicznego i parametrów mikrostrukturalnych. Badano kompozyty wykonane z mączką ceglaną jako prekursorem oraz z odmianami aktywatorów alkalicznych o różnym module krzemianowym (Ms = 0,8, 1,0,1,2, 1,4 i 1,6). Wypełniaczem stosowanym w przypadku dwóch pierwszych zestawów kompozytów był piasek kwarcowy, natomiast w przypadku dwóch pozostałych gruz ceglany. Warianty zakresu wielkości cząstek prekursora wynosiły: $0 \div 1 \mathrm{~mm}$ i $0 \div 0,3 \mathrm{~mm}$. Próbki do badań miały wymiary nominalne $40 \times 40 \times 160 \mathrm{~mm}$ i po 28 dniach utwardzania były zaopatrzone w nacięcia w połowie rozpiętości. Karby sięgały do $1 / 3$ wysokości próbek, które poddano testom zginania trójpunktowego, w których rejestrowano wykresy siła w funkcji przemieszczenia. Wartości statycznego modułu sprężystości, efektywnej odporności na kruche pękanie, efektywnej wiązkości i właściwej energii pękania wyznaczono za pomocą modelu efektywnego pękania i metody pracy z pękaniem. Jednocześnie określono wartości statycznego modułu sprężystości, wytrzymałości na rozciąganie i właściwej energii pękania metodą odwrotną opartą na zespole sieci neuronowej. Zmierzone i zidentyfikowane parametry są bardzo zgodne. Moduł krzemianowy, rodzaj wypełniacza oraz uszlachetnienie prekursora istotnie wpływały na parametry pękania mechanicznego kompozytów. Opisano również mikrostrukturę kompozytów z grubszym prekursorem.

\section{SŁOWA KLUCZOWE:}

aktywowany alkaliami, sztuczna sieć neuronowa, test pękania, wykres obciążenie-przemieszczenie, parametry pękania mechanicznego 